Prepared in cooperation with the Federal Highway Administration

\title{
Assessment of Bridge Scour Countermeasures at Selected Bridges in the United States, 2014-18
}

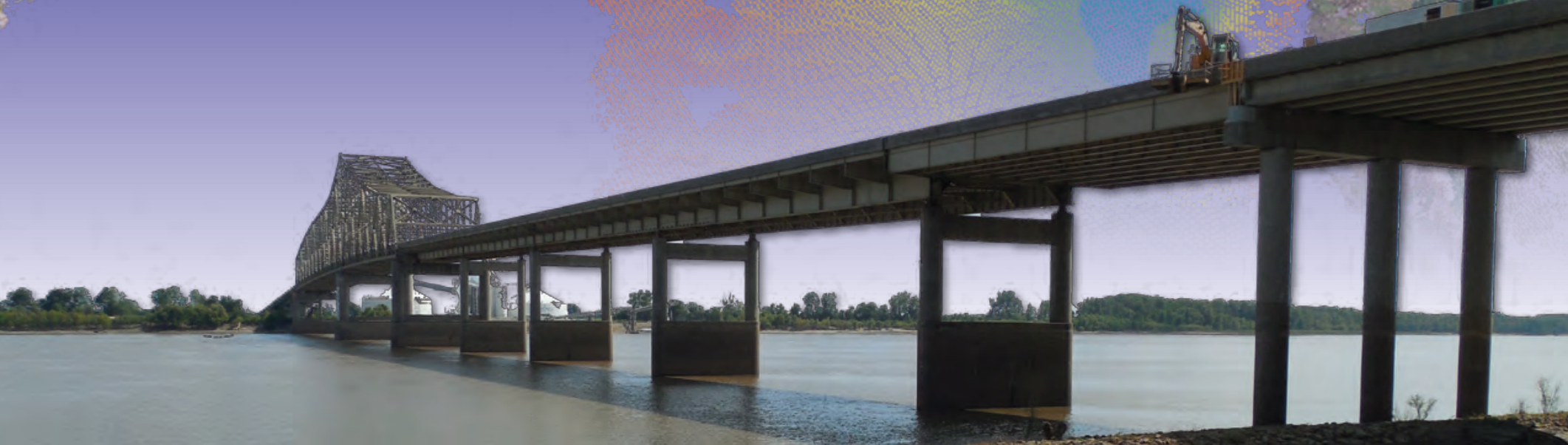

Scientific Investigations Report 2019-5080

U.S. Department of the Interior U.S. Geological Survey 
Cover: (Top) Combined lidar and bathymetry image of the bridge over the Upper lowa River at IA-76 near Dorchester, Iowa (site 030). (Bottom) Bridge over the Mississippi River near Caruthersville, Missouri (site 004). Photo by Richard Huizinga, U.S. Geological Survey. 


\section{Assessment of Bridge Scour Counter- measures at Selected Bridges in the United States, 2014-18}

By Thomas P. Suro, Richard J. Huizinga, Ryan L. Fosness, and Taylor J. Dudunake

Prepared in cooperation with the Federal Highway Administration

Scientific Investigations Report 2019-5080 


\title{
U.S. Department of the Interior \\ DAVID BERNHARDT, Secretary
}

\author{
U.S. Geological Survey \\ James F. Reilly II, Director
}

U.S. Geological Survey, Reston, Virginia: 2020

For more information on the USGS —-the Federal source for science about the Earth, its natural and living resources, natural hazards, and the environment-visit https://www.usgs.gov or call 1-888-ASK-USGS.

For an overview of USGS information products, including maps, imagery, and publications,

visit https://store.usgs.gov.

Any use of trade, firm, or product names is for descriptive purposes only and does not imply endorsement by the U.S. Government.

Although this information product, for the most part, is in the public domain, it also may contain copyrighted materials as noted in the text. Permission to reproduce copyrighted items must be secured from the copyright owner.

Suggested citation:

Suro, T.P., Huizinga, R.J., Fosness, R.L., and Dudunake, T.J., 2020, Assessment of bridge scour countermeasures at selected bridges in the United States, 2014-18: U.S. Geological Survey Scientific Investigations Report 2019-5080, 29 p., https://doi.org/10.3133/sir20195080.

Associated data for this publication:

Dudunake, T.J., 2017, Geospatial data for bridge scour countermeasure assessments at select bridges in the United States, 2014 to 2016: U.S. Geological Survey data release, https://doi.org/10.5066/F71R6N02.

Dudunake, T.J., 2019, Geospatial data for bridge scour countermeasure assessments at select bridges in the United States, 2016-18: U.S. Geological Survey data release, https://doi.org/10.5066/F7WW7G4W. 


\section{Acknowledgments}

The authors would like to express their appreciation to the Departments of Transportation in the 11 cooperating States (Connecticut, Florida, Idaho, Illinois, lowa, Missouri, Montana, New Jersey, Pennsylvania, South Carolina, and Tennessee), to Daniel Ghere, David Henderson, Kornel Kerenyi, and the Hydraulics Research and Development Program Staff at the Federal Highway Administration who assisted in the study. The authors would like to also express their appreciation and gratitude to their U.S. Geological Survey (USGS) colleagues Peter Cinotto, Chad Wagner, Rich Akins, Justin Boldt, Keith Cobb, Jerilyn Collenburg, Brenda Densmore, Ben Dietsch, Jarrett Ellis, Wladmir Guimaraes, Steve Holnbeck, Justin Krahulik, Sean Lawlor, Kathryn Lee (former USGS employee), Mike Linhart (former USGS employee), Michal Niemoczynski, Ben Rivers, Patricia Sadler, Jason Shvanda, Kevin Townsend, and Ben Sleeper (former USGS employee). 



\section{Contents}

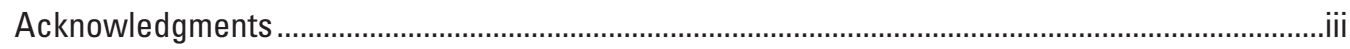

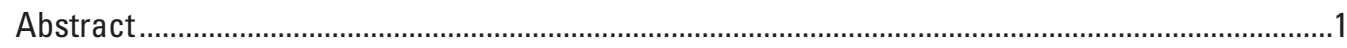

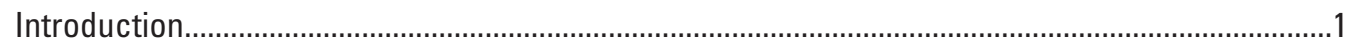

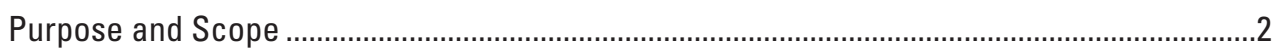

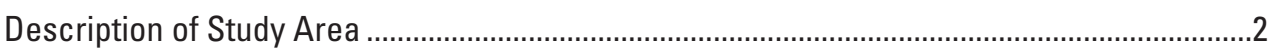

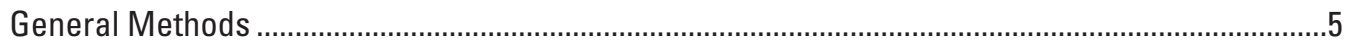

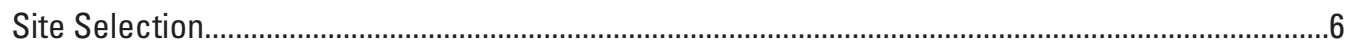

Procedures for Survey Data Collection and Site Evaluation ...........................................................

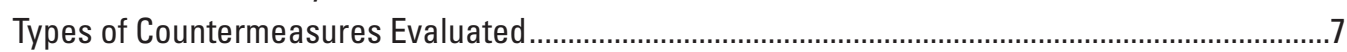

Riprap Countermeasure Evaluation .................................................................................

A-Jacks and Cabled Concrete Mattress Countermeasure Evaluation......................................8

Gabion Baskets and Articulating Concrete Block Countermeasure Evaluation ......................13

Procedures for Bathymetric and Topographic Data Collection and Processing.............................16

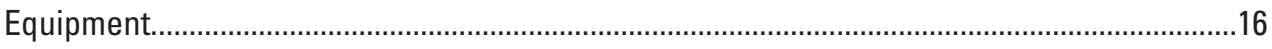

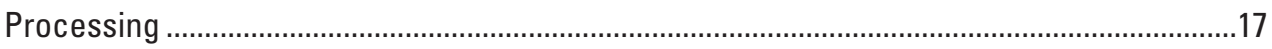

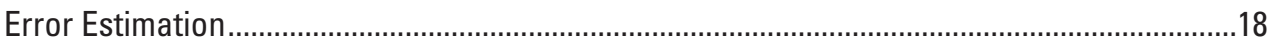

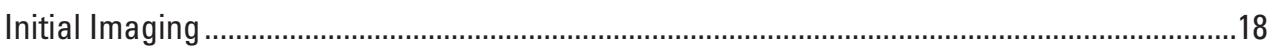

High-Resolution Data Collection and Processing ....................................................................20

Additional Data Collection with Tripod-Mounted Terrestrial Lidar Systems ..........................20

Flood History at Study Sites ...............................................................................................................25

Peak Streamflow History Since Countermeasures Were Installed .......................................25

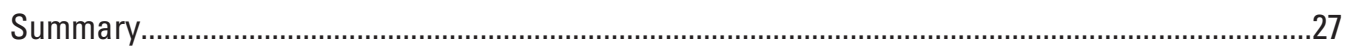

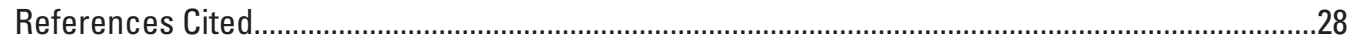




\section{Figures}

1. Map showing bridge scour countermeasure assessment sites used in this study throughout the United States, 2014-18.

2. Oblique view showing the topographic point cloud data from the terrestrial lidar survey of site 031, the Wapsipinicon River at structure 20740 on U.S. Highway 30 near Wheatland, lowa, on December 17, 2017 .6

3. Photograph showing view of downstream side of bridge at site 011 over Grand River at Route A near McFall, Missouri, showing riprap on right bank, debris on right pier, and deposited sand bar with minor scour hole on left bank

4. Photograph showing side-scan sonar image of base of riprap on right bank at site 011, Grand River at Route A near McFall, Missouri

5. Wolman Particle Count chart for riprap on right bank at site 011, Grand River at Route A near McFall, Missouri.

6. Photograph showing A-Jack countermeasures interlocked along abutment slope at site 006 on the Snake River in Idaho

7. Photograph showing A-Jack countermeasures remain relatively unchanged and effective since installation in 2002 at site 006, Snake River at Shelley West River Road near Shelley, Idaho

8. Photographs showing $A, A$-Jack countermeasures installed around pier 2 at site 006 are visible with underwater videography and appear intact and effective; $B$, A-Jack countermeasures installed on toe of abutment slope and around piers 1 and 3 at site 006 along the Snake River in Idaho are mostly covered or embedded with gravel and sediment

9. Photographs showing distressed cabled-concrete mattress countermeasures installed at site 019, Gallatin River at I-90 near

Manhattan, Montana

10. Photographs showing $A$, Gabion baskets installed around upstream right side of Site 028, a bridge over Smith Branch along Clement Road in Columbia, South Carolina, showing some signs of shifting near toe of embankment; $B$, Gabion baskets installed around upstream left side of bridge over Smith Branch showing more signs of shifting and the edge of the baskets was scoured, lifted, and folded over itself

11. Photograph showing sanitary sewer pipe line across Smith Branch, site 028, Columbia, South Carolina, just upstream of original upstream extent of Gabion mattress countermeasure installation...

12. Photograph showing vessel mounted Teledyne-Optech ILRIS High Density Enhanced Range laser scanner

13. Oblique view of the bathymetric survey of the scour countermeasures near $A$, upstream pier 3 , and $B$, downstream pier 5 of site 007 at structures 097-0003/0004 on Interstate 64 over the Wabash River near Grayville, Illinois, showing original resolution data from the May 2, 2016 survey

14. Oblique view of the bathymetric survey of the scour countermeasures at site 007 of structures 097-0003/0004 on Interstate 64 over the Wabash River near Grayville, Illinois, near upstream pier 3 showing $A$, original resolution data from the May 2, 2016 survey, and $B$, high-resolution data from the August 27, 2018 survey, and near downstream pier 5 showing $C$, original resolution data from the May 2, 2016 survey, and D, high-resolution data from the August 27, 2018 survey 
15. Photographs showing $A$, Teledyne-Optech ILRIS High Density Enhanced Range laser scanner, $B$, FAR0 Focus 3D X130 laser scanner setup, and $C$, Trimble VX Stationary three-dimensional single-laser scanner, all shown mounted on tripods

16. Oblique view of the terrestrial lidar scanned data merged with channel bathymetry survey data of the bridge and river channel at site 004, Interstate 155 over the Mississippi River near Caruthersville, Missouri, from May 3, 2016

17. Plot of 1-percent annual exceedance probability discharge and maximum recorded discharge since countermeasures were installed at 34 study sites

\section{Tables}

1. List of bridge scour sites, category, and countermeasure type used in this study throughout the United States, 2014-18.

2. List of bridge scour countermeasure assessment sites where terrestrial lidar was used to scan above water features

3. Peak streamflow since scour countermeasures were installed, 1-percent annual exceedance probability, and 1-percent annual exceedance probability discharge at 34 bridge-scour countermeasure assessment sites used in this study 


\section{Conversion Factors}

U.S. customary units to International System of Units

\begin{tabular}{|c|c|c|}
\hline Multiply & By & To obtain \\
\hline \multicolumn{3}{|c|}{ Length } \\
\hline foot $(\mathrm{ft})$ & 0.3048 & meter $(\mathrm{m})$ \\
\hline mile (mi) & 1.609 & kilometer $(\mathrm{km})$ \\
\hline \multicolumn{3}{|c|}{ Area } \\
\hline square mile $\left(\mathrm{mi}^{2}\right)$ & 259.0 & hectare (ha) \\
\hline square mile $\left(\mathrm{mi}^{2}\right)$ & 2.590 & square kilometer $\left(\mathrm{km}^{2}\right)$ \\
\hline \multicolumn{3}{|c|}{ Volume } \\
\hline cubic foot $\left(\mathrm{ft}^{3}\right)$ & 28.32 & cubic decimeter $\left(\mathrm{dm}^{3}\right)$ \\
\hline cubic foot $\left(\mathrm{ft}^{3}\right)$ & 0.02832 & cubic meter $\left(\mathrm{m}^{3}\right)$ \\
\hline \multicolumn{3}{|c|}{ Flow rate } \\
\hline cubic foot per second $\left(\mathrm{ft}^{3} / \mathrm{s}\right)$ & 0.02832 & cubic meter per second $\left(\mathrm{m}^{3} / \mathrm{s}\right)$ \\
\hline $\begin{array}{l}\text { cubic foot per second per square } \\
\text { mile }\left(\left[\mathrm{ft}^{3} / \mathrm{s}\right] / \mathrm{mi}^{2}\right)\end{array}$ & 0.01093 & $\begin{array}{l}\text { cubic meter per second per } \\
\text { square kilometer }\left(\left[\mathrm{m}^{3} / \mathrm{s}\right] / \mathrm{km}^{2}\right)\end{array}$ \\
\hline \multicolumn{3}{|c|}{ International System of Units to U.S. customary units } \\
\hline Multiply & By & To obtain \\
\hline \multicolumn{3}{|c|}{ Length } \\
\hline centimeter $(\mathrm{cm})$ & 0.3937 & inch (in.) \\
\hline millimeter $(\mathrm{mm})$ & 0.03937 & inch (in.) \\
\hline meter $(\mathrm{m})$ & 3.281 & foot $(\mathrm{ft})$ \\
\hline \multicolumn{3}{|c|}{ Area } \\
\hline square meter $\left(\mathrm{m}^{2}\right)$ & 0.0002471 & acre \\
\hline square kilometer $\left(\mathrm{km}^{2}\right)$ & 247.1 & acre \\
\hline square meter $\left(\mathrm{m}^{2}\right)$ & 10.76 & square foot $\left(\mathrm{ft}^{2}\right)$ \\
\hline hectare (ha) & 0.003861 & square mile $\left(\mathrm{mi}^{2}\right)$ \\
\hline square kilometer $\left(\mathrm{km}^{2}\right)$ & 0.3861 & square mile $\left(\mathrm{mi}^{2}\right)$ \\
\hline \multicolumn{3}{|c|}{ Volume } \\
\hline cubic meter $\left(\mathrm{m}^{3}\right)$ & 0.0002642 & million gallons (Mgal) \\
\hline cubic meter $\left(\mathrm{m}^{3}\right)$ & 35.31 & cubic foot $\left(\mathrm{ft}^{3}\right)$ \\
\hline cubic meter $\left(\mathrm{m}^{3}\right)$ & 1.308 & cubic yard $\left(\mathrm{yd}^{3}\right)$ \\
\hline \multicolumn{3}{|c|}{ Flow rate } \\
\hline cubic meter per second $\left(\mathrm{m}^{3} / \mathrm{s}\right)$ & 35.31 & cubic foot per second $\left(\mathrm{ft}^{3} / \mathrm{s}\right)$ \\
\hline cubic meter per second $\left(\mathrm{m}^{3} / \mathrm{s}\right)$ & 22.83 & million gallons per day $(\mathrm{Mgal} / \mathrm{d})$ \\
\hline
\end{tabular}

Temperature in degrees Celsius $\left({ }^{\circ} \mathrm{C}\right)$ may be converted to degrees Fahrenheit $\left({ }^{\circ} \mathrm{F}\right)$ as follows:

$$
{ }^{\circ} \mathrm{F}=\left(1.8 \times{ }^{\circ} \mathrm{C}\right)+32 .
$$

Temperature in degrees Fahrenheit $\left({ }^{\circ} \mathrm{F}\right)$ may be converted to degrees Celsius $\left({ }^{\circ} \mathrm{C}\right)$ as follows:

$$
{ }^{\circ} \mathrm{C}=\left({ }^{\circ} \mathrm{F}-32\right) / 1.8 \text {. }
$$




\section{Datum}

Vertical coordinate information is referenced to the North American Vertical Datum of 1988 (NAVD 88).

Horizontal coordinate information is referenced to the North American Datum of 1983 (NAD 83).

Elevation, as used in this report, refers to distance above the vertical datum.

\section{Abbreviations}

$\begin{array}{ll}\text { AEP } & \text { annual exceedance probability } \\ \text { DOT } & \text { Department of Transportation } \\ \text { FHWA } & \text { Federal Highway Administration } \\ \text { HEC } & \text { Hydraulic Engineering Circular } \\ \text { INS } & \text { Inertial navigation system } \\ \text { MBES } & \text { multibeam echo sounder } \\ \text { NBI } & \text { National Bridge Inventory } \\ \text { NWIS } & \text { U.S. Geological Survey National Water Information System } \\ \text { OFR } & \text { Open-File Report } \\ \text { RI } & \text { recurrence interval } \\ \text { RTK-GNSS } & \text { real-time kinematic-global navigation satellite system } \\ \text { SBES } & \text { single beam echosounder } \\ \text { T-lidar } & \text { terrestrial light detection and ranging technology } \\ \text { USACE } & \text { U.S. Army Corps of Engineers } \\ \text { USGS } & \text { U.S. Geological Survey }\end{array}$





\title{
Assessment of Bridge Scour Countermeasures at Selected Bridges in the United States, 2014-18
}

\author{
By Thomas P. Suro, Richard J. Huizinga, Ryan L. Fosness, and Taylor J. Dudunake
}

\section{Abstract}

Erosion of the streambed, known also as scour, around pier 3 of the New York State Thruway bridge over Schoharie Creek caused the pier to fail, which ultimately resulted in bridge failure during the flooding event of April 5, 1987. The Federal Highway Administration (FHWA) responded to the need for better guidance on the evaluation of bridge scour and the selection and installation of scour countermeasures with the release of several Hydraulic Engineering Circulars. Although this information has been available, used, and updated over the years, an evaluation of the current conditions of scour countermeasures has not been performed. Therefore, the U.S. Geological Survey, in cooperation with the FHWA, began a study in 2013 to assess the current conditions of bridge scour countermeasures at selected sites around the country. The bridge scour countermeasure site assessments included reviewing countermeasure design plans, field inspections, traditional surveys, motion-compensated terrestrial light detection and ranging technology (lidar), high-resolution multi-beam bathymetry scanning, underwater video imaging, and a review of the peak and daily streamflow history for the associated river or stream. A total of 34 bridge scour countermeasure sites were selected in 11 states for this study. The types of countermeasures installed at the bridge scour study sites ranged from riprap, the most common countermeasure in the study, to A-Jacks and cabled-concrete mattresses.

The installed countermeasures were generally exposed to hydraulic forces from floods that equaled or exceeded the 1-percent, and even the 0.2-percent, annual exceedance probability at some of the study sites, but not all. The field inspections and countermeasure evaluations identified areas of shifting, slumping, and some scour holes and damage or washouts to the countermeasures, but generally most remained in place. The high-resolution laser scanner data, photo imaging and traditional survey data, and field notes were provided to the FHWA for expert evaluation of the bridge scour countermeasure performance.

\section{Introduction}

Although the science and engineering community were aware of the physical process of scour in rivers and streams, the catastrophic bridge failure of the New York State Thruway bridge over Schoharie Creek on April 5, 1987, transformed the understanding of how much risk is associated with scour around bridges. This tragic event resulted in the loss of 10 lives (Zembrzuski and Evans, 1989) and unfortunately, another bridge failure due to scour happened 2 years later, on April 1, 1989, along US-51 over the Hatchie River in Tennessee (Bryan, 1989). These catastrophic bridge failures prompted the Federal Highway Administration (FHWA) to publish Hydraulic Engineering Circulars (HECs) 18, 20, and 23 to provide guidance on the evaluation of bridge scour (Federal Highway Administration, 2009, 2012a, 2012b). The FHWA also initiated a national program, under state jurisdiction, to evaluate the susceptibility of existing bridges to scour. Many states conducted different levels of bridge assessments using the methods presented in HEC 18 (Federal Highway Administration, 2012a).

Recognizing that potential scour can be estimated by use of these methods, different types of scour countermeasures were employed to abate pier and abutment scour around bridges. Bridge scour countermeasures protect transportation infrastructure by reducing the potential of sediment scour at locations susceptible to scour around bridge structures. After many years of relying on HEC 18, the FHWA understood the need to provide better guidance on scour countermeasure selection and design. In 2001, the FHWA published HEC No. 23, which was revised to a third edition in 2009 (HEC-23; Federal Highway Administration, 2009) to provide specific selection, design, and implementation guidelines for bridge scour and stream instability countermeasures. Although additional guidelines have been released and updated over the years, the effectiveness of countermeasures installed at bridges since FHWA HEC 23 guidelines were released has not been evaluated. In 2013, the U.S. Geological Survey (USGS), in cooperation with the FHWA, began this study to assess the current condition of bridge scour countermeasures at selected sites across the United States. 


\section{Purpose and Scope}

This report summarizes the countermeasure site assessment data collected from 2014 through 2018 at 34 selected bridges across the United States. The drainage areas of the selected bridge sites ranged from about 10 square miles $\left(\mathrm{mi}^{2}\right)$ to more than $29,000 \mathrm{mi}^{2}$. The assessment included site visits to survey and document the current conditions of installed countermeasures, an analysis of the computed peak flow at each site since the installation of countermeasures, and a review of the daily streamflow history at a nearby USGS streamgage. The project generally focused on local pier and abutment scour countermeasures, and utilized multi-beam bathymetry surveys, side-scan sonar, underwater cameras, and traditional survey and probing techniques. The bridge site assessment data collected during this study are published in two USGS Open-File Reports (Dudunake and others, 2017, 2019) and related data are available in companion data releases available at the USGS ScienceBase repository (Dudunake, 2017, 2019).

\section{Description of Study Area}

The study includes assessments of 34 bridge sites in 11 States: Connecticut, Florida, Idaho, Illinois, Iowa, Missouri, Montana, New Jersey, Pennsylvania, South Carolina, and Tennessee (fig. 1, table 1). These sites represent various river and bridge sizes, streamflow magnitudes, and countermeasure types. Bridge sites for this study were selected from a combination of sources including the National Bridge Inventory (NBI) and State Department of Transportation databases. Bridge selection was restricted to sites that met the following criteria: (1) the site had bridge scour countermeasures designed according to HEC 23 guidelines already installed at the site, (2) the site was near an existing streamgage with available daily and peak streamflow record, and (3) the site had experienced a significant streamflow event after the countermeasure was installed, defined as a peak streamflow with an estimated annual exceedance probability (AEP) of less than or equal to about 4 percent (25-year or greater recurrence interval).

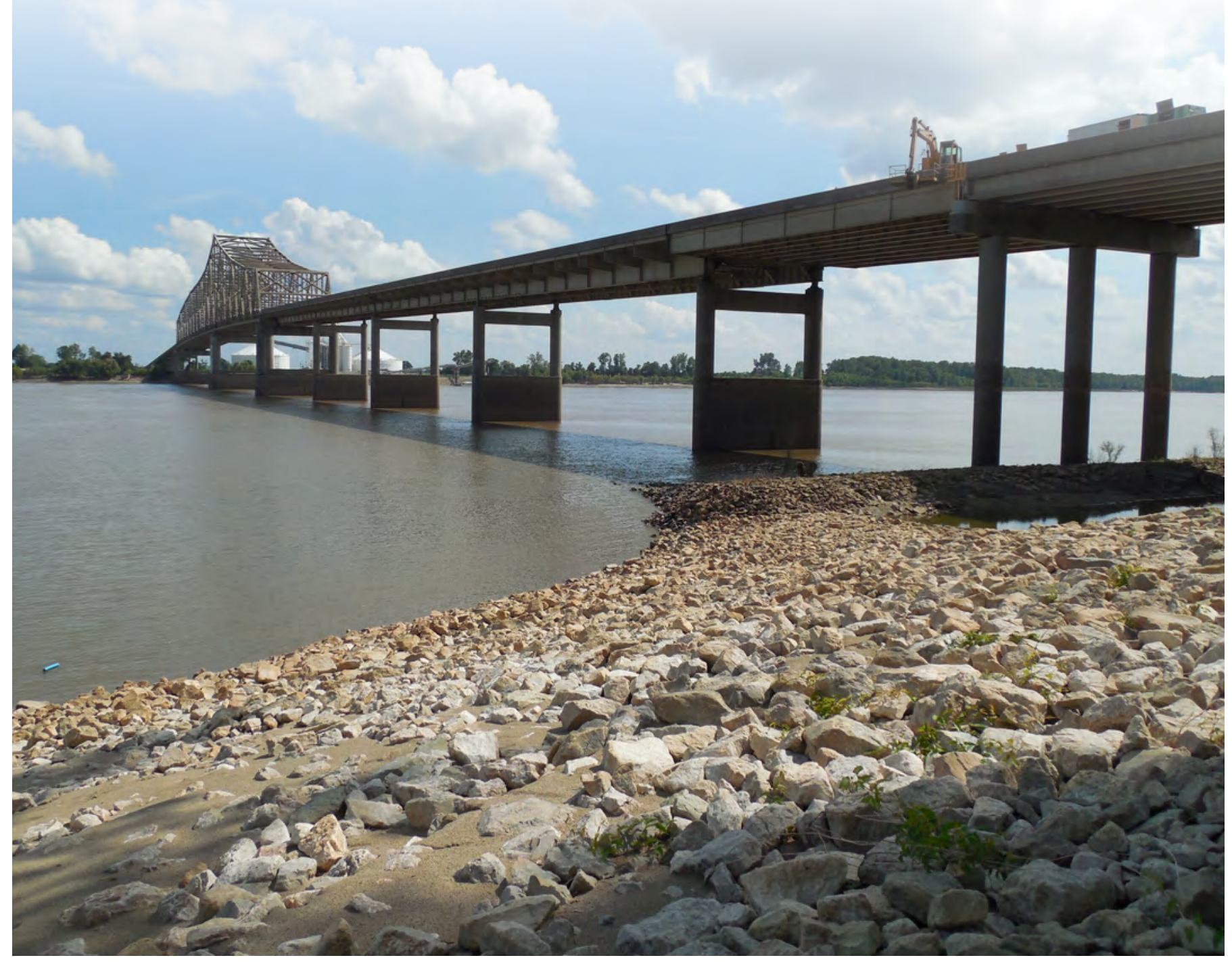

Photograph of scour countermeasures along right bank of the Mississippi River near Caruthersville, Missouri. Photograph by Richard Huizinga, U.S. Geological Survey. 


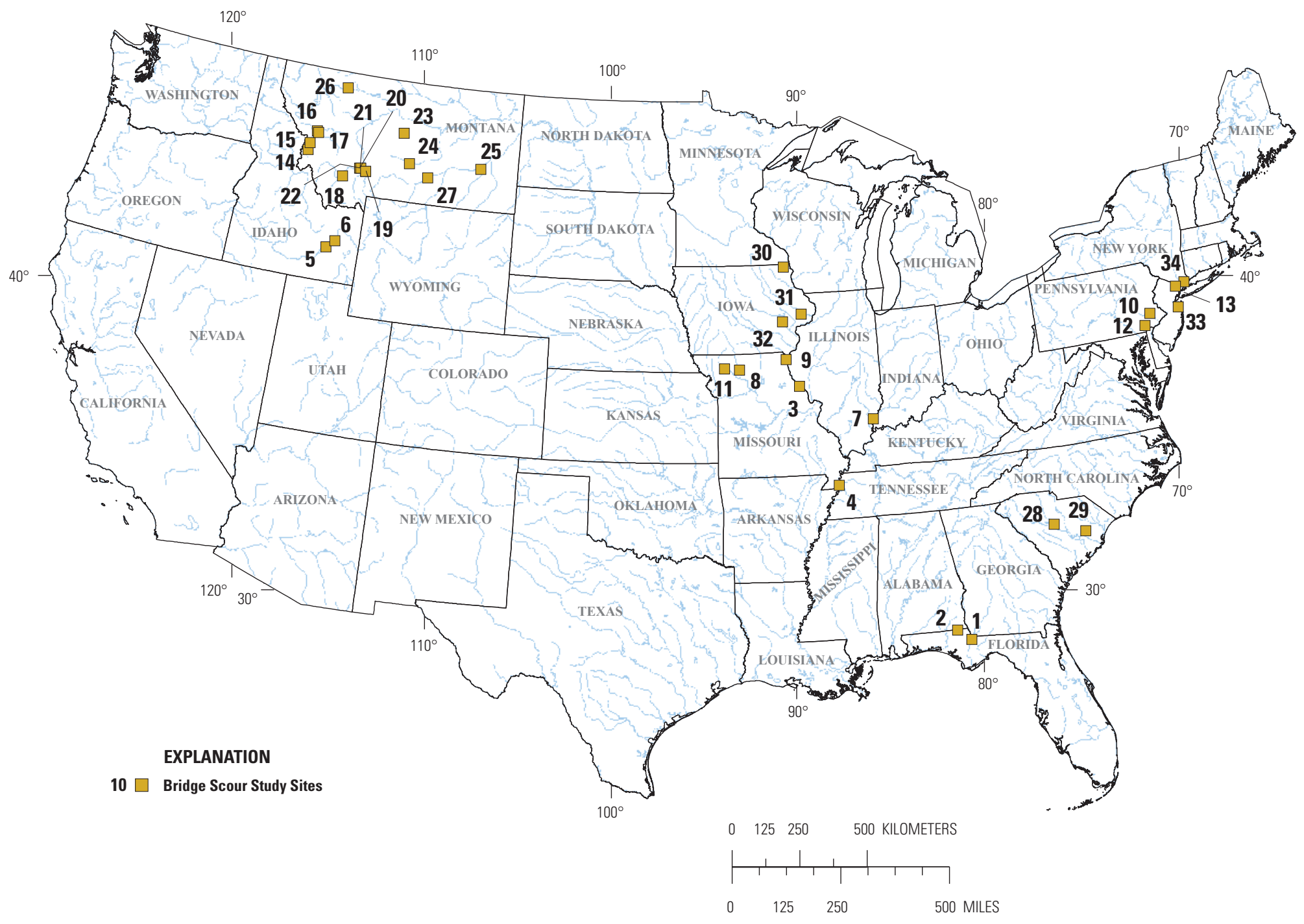


Table 1. List of bridge scour sites, category, and countermeasure type used in this study throughout the United States, 2014-18.

[FL, Florida; MO, Missouri; IL, Illinois; TN, Tennessee; ID, Idaho; IN, Indiana; PA, Pennsylvania; CT, Connecticut; MT, Montana; SC, South Carolina; IA, Iowa; NJ, New Jersey; ACB, articulated concrete block; CCM, cabled-concrete mattress]

\begin{tabular}{|c|c|c|c|c|c|}
\hline $\begin{array}{c}\text { Site } \\
\text { identifier }\end{array}$ & Category & Watercourse & State & Site name & $\begin{array}{c}\text { Countermeasure } \\
\text { type }\end{array}$ \\
\hline 1 & 1,2 & Apalachicola River & FL & Apalachicola River at I-10 near Chattahoochee, FL & Riprap \\
\hline 2 & 5 & Spring Creek & FL & Spring Creek at US-231 near Campbellton, FL & Gabions \\
\hline 3 & 1,2 & Mississippi River & $\mathrm{MO} / \mathrm{IL}$ & Mississippi River at US-54 at Louisiana, MO & Riprap \\
\hline 4 & 1,2 & Mississippi River & $\mathrm{MO} / \mathrm{TN}$ & Mississippi River at I-155 near Caruthersville, MO & Riprap \\
\hline 5 & 1,2 & Snake River & ID & Snake River at Ferry Butte Rd (W 500 S), Bingham County, ID & A-Jacks \\
\hline 6 & 1,2 & Snake River & ID & Snake River at Shelley West River Rd (E 1250 N) near Shelley, ID & A-Jacks \\
\hline 7 & 1,2 & Wabash River & $\mathrm{IL} / \mathrm{IN}$ & Wabash River at I-64 near Grayville, IL & Riprap \\
\hline 8 & 3,4 & Thompson River & MO & Thompson River at MO-6 near Trenton, MO & Riprap \\
\hline 9 & 5,6 & Fox River & MO & Fox River at US-61 near Wayland, MO & Riprap \\
\hline 10 & 8 & Perkiomen Creek and Mill Race & PA & Perkiomen Creek and Mill Race at SR 1024 (Salford Station Rd) near Perkiomenville, PA & Riprap \\
\hline 11 & 3,4 & Grand River & MO & Grand River at Rte-A near McFall, MO & Riprap \\
\hline 12 & 8 & WB Brandywine Creek & PA & West Branch Brandywine Creek at SR 3062 (Strasburg Rd) near Coatesville, PA & Riprap \\
\hline 13 & 8 & Byram River & $\mathrm{CT}$ & Byram River at Sherwood Ave at Greenwich, CT & $\mathrm{ACB}$ \\
\hline 14 & 8 & Bitterroot River & MT & Bitterroot River at US-93 near Hamilton, MT & $\mathrm{CCM}$ \\
\hline 15 & 3 & Bitterroot River & MT & Bitterroot River at Bell Crossing near Victor, MT & $\mathrm{ACB}$ \\
\hline 16 & 3 & Blackfoot River & MT & Blackfoot River at I-90 at Bonner, MT & A-Jacks and Riprap \\
\hline 17 & 8 & Clark Fork River & MT & Clark Fork River at Turah Rd near Bonner, MT & $\mathrm{CCM}$ \\
\hline 18 & 8 & Beaverhead River & MT & Beaverhead River at MT-41 at Twin Bridges, MT & Riprap \\
\hline 19 & 8 & Gallatin River & MT & Gallatin River at I-90 near Manhattan, MT & $\mathrm{CCM}$ \\
\hline 20 & 8 & Jefferson River & MT & Jefferson River at MT-2 near Three Forks, MT & Riprap \\
\hline 21 & 8 & Madison River & MT & Madison River at I-90 near Three Forks, MT & $\mathrm{CCM}$ \\
\hline 22 & 8 & Gallatin River & MT & Gallatin River at S-205 near Manhattan, MT & CCM and Riprap \\
\hline 23 & 9 & Judith River & MT & Judith River at MT-81 near Lewistown, MT & Riprap \\
\hline 24 & 9 & Musselshell River & MT & Musselshell River at S-300 at Ryegate, MT & Riprap \\
\hline 25 & 8 & Tongue River & MT & Tongue River at I-94 at Miles City, MT & Riprap \\
\hline 26 & 9 & Two Medicine River & MT & Two Medicine River at US-89 near Browning, MT & CCM and Riprap \\
\hline 27 & 3 & Yellowstone River & MT & Yellowstone River at Hwy 312 at Huntley, MT & CCM and Riprap \\
\hline 28 & 5,6 & Smith Branch & $\mathrm{SC}$ & Smith Branch at S-126 (Clement Rd) at Columbia, SC & Gabions \\
\hline 29 & 3,4 & Black River & $\mathrm{SC}$ & Black River at US-52 at Kingstree, SC & Gabions \\
\hline 30 & 3,4 & Upper Iowa River & IA & Upper Iowa River at IA-76 near Dorchester, IA & Riprap \\
\hline 31 & 3,4 & Wapsipinicon River & IA & Wapsipinicon River at US-30 near Wheatland, IA & Riprap \\
\hline 32 & 5,6 & Old Man's Creek & IA & Old Man's Creek at IA-1 near Iowa City, IA & Riprap \\
\hline 33 & 5,6 & Yellow Brook & $\mathrm{NJ}$ & Yellow Brook at NJ-34 at Colts Neck Township, NJ & Gabions \\
\hline 34 & 5 & Saddle River & NJ & Saddle River at NJ-17 at Ridgewood, NJ & $\mathrm{ACB}$ \\
\hline
\end{tabular}




\section{General Methods}

After the April 1987 collapse of the New York State Thruway Bridge over Schoharie Creek, a National Scour Evaluation Program was established. The original Technical Advisory was superseded in 1991 to provide more guidance on the development and implementation of procedures for evaluation of bridge scour. Since 1991, many advances have been made in estimating scour at bridge crossings and in the design of scour countermeasures (Federal Highway Administration, 2012a, 2012b), but there has not been a comprehensive evaluation of the long-term performance of these bridge scour countermeasures. This study focused on collecting data to assess the current condition of bridge scour countermeasures, primarily those used to armor the streambed or streambank around bridge structures. Several types of countermeasures were included in this study, including riprap, articulated concrete blocks, concrete armor units, and Gabion mattresses. Data collection was standardized using consistent field forms and procedures for collecting topographic surveys and bathymetric surveys, as well as Wolman particle counts (Federal Highway Administration, 2016) at sites that used riprap as the primary countermeasure. Traditional survey methods were used at smaller bridge sites, but larger bridges were surveyed using laser imaging technology (table 2). Field crews utilized motion-compensated terrestrial light detection and ranging technology (T-lidar) to capture high-resolution topography data for areas above the water surface and below the estimated peak-flow stage at these larger bridges. T-lidar technology uses rapidly moving laser pulses transmitted from the survey instrument that reflect off the structure or landscape and back to the instrument. The instrument then calculates the distance of the returned pulse based on the incoming velocity (Kimbrow and Lee, 2013). Field crews utilized a fixed tripod mount system and a motion-compensated, boat-mounted T-lidar system to collect data for this study. An example of T-lidar data collection at site 031, Wapsipinicon River at structure 20740 on U.S. Highway 30 near Wheatland, Iowa, is shown in figure 2.

Bridges that spanned large, deep rivers were identified as Category 1 and 2 (Dudunake and others, 2017), requiring the use of a manned boat to collect bathymetric data. The depths at these sites generally equaled or exceeded 15 feet (ft), which made them candidates for using a multibeam echosounder (MBES) to acquire bathymetric data. The MBES was coupled with real-time kinematic global navigation satellite systems

Table 2. List of bridge scour countermeasure assessment sites where terrestrial lidar was used to scan above water features.

[FL, Florida; MO, Missouri; IL, Illinois; SC, South Carolina; IA, Iowa]

\begin{tabular}{|c|c|c|c|}
\hline $\begin{array}{c}\text { Site } \\
\text { identifier }\end{array}$ & Site name & Category & Countermeasure type \\
\hline 1 & Apalachicola River at I-10 near Chattahoochee, FL & 1,2 & Riprap \\
\hline 2 & Spring Creek at US-231 near Campbellton, FL & 5 & Gabion \\
\hline 3 & Mississippi River at US-54 at Louisiana, MO & 1,2 & Riprap \\
\hline 7 & Wabash River at I-64 near Grayville, IL & 1,2 & Riprap \\
\hline 8 & Thompson River at MO-6 near Trenton, MO & 3,4 & Riprap \\
\hline 28 & Smith Branch at S-126 (Clement Rd) at Columbia, SC & 5,6 & Gabion \\
\hline 29 & Black River at US-52 at Kingstree, SC & 3,4 & Gabion \\
\hline 30 & Upper Iowa River at IA-76 near Dorchester, IA & 3,4 & Riprap \\
\hline 31 & Wapsipinicon River at US-30 near Wheatland, IA & 3,4 & Riprap \\
\hline 32 & Old Man's Creek at IA-1 near Iowa City, IA & 5,6 & Riprap \\
\hline
\end{tabular}




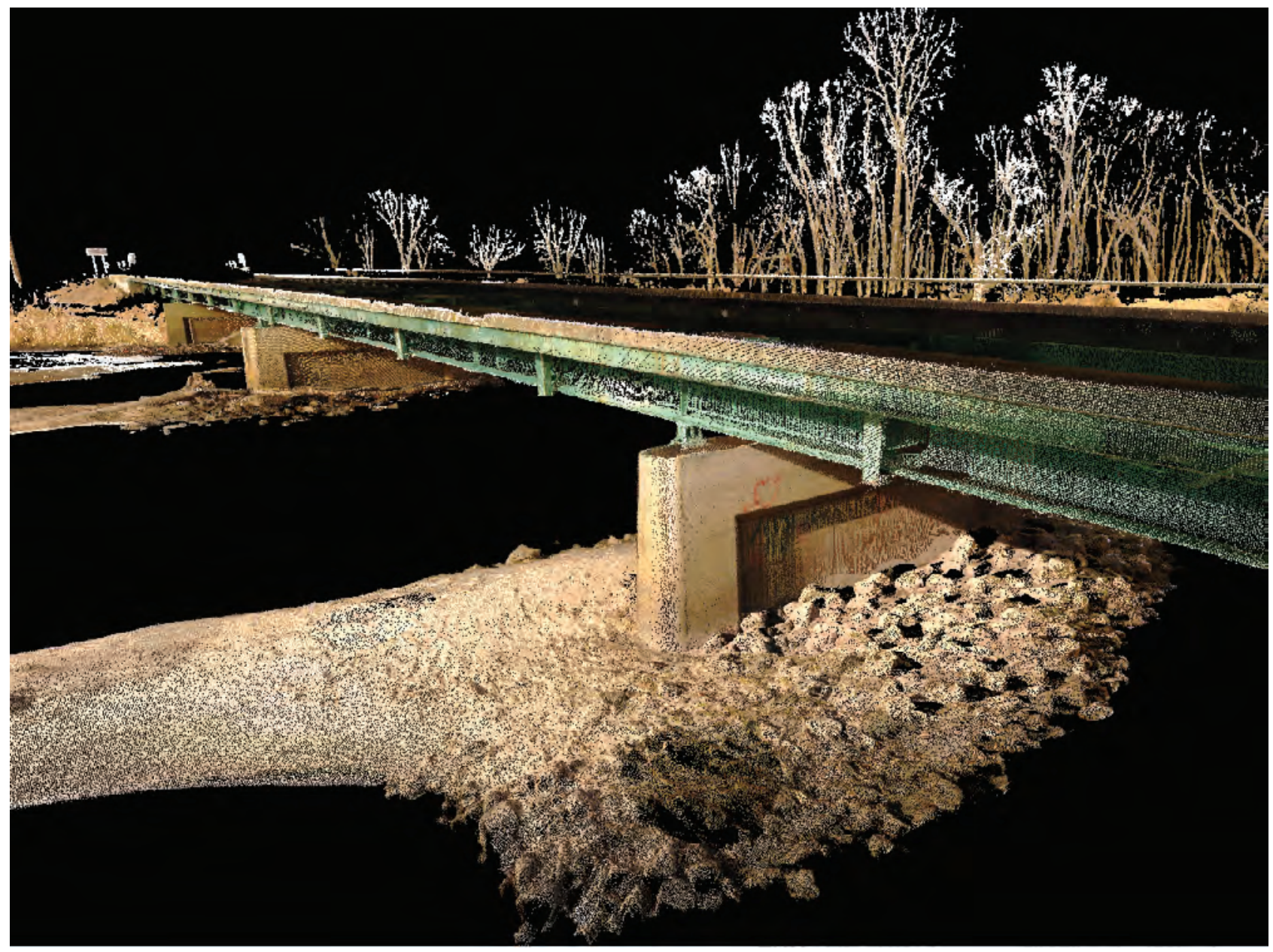

Figure 2. Oblique view (from downstream left [southeast]) showing the topographic point cloud data from the terrestrial lidar survey of site 031, the Wapsipinicon River at structure 20740 on U.S. Highway 30 near Wheatland, lowa, on December 17, 2017. Topographic points are colored based on concurrent photos taken during the survey.

(RTK-GNSS) to provide reference position and elevation data for the surveys. If a bridge site had clear water conditions during the survey, gridded underwater camera systems were available to provide images of the submerged countermeasures. Details of MBES data processing and imaging of submerged countermeasures are provided in a later section of this report, titled "Procedures for Bathymetric and Topographic Data Collection and Processing."

A Wolman particle size count analysis was performed at 21 of the study sites used in this report to determine the riprap gradation. This is a manual process that involves measuring the size of random particles (rocks or riprap) along equal sampling intervals until a minimum of 100 particles have been measured. Once the particles have been measured, a gradation curve can be developed based on the frequency distribution of various sizes of rock measured.

A site-selection criterion was established to limit the study to countermeasure sites that were designed using FHWA guidelines, where a history of daily and peak-streamflow records were available or could be reliably estimated. The following section describes the general site selection criterion used for this study.

\section{Site Selection}

The bridge scour countermeasure sites for this study were selected jointly by the USGS and FHWA. Sites were selected from the NBI and State Departments of Transportation databases using the following criteria:

1. The site had bridge scour countermeasures in place that were designed according to HEC 23 guidelines.

2. The site spanned a stream that had an existing continuous-record streamgage, with daily and peak streamflow records that preceded the installation of the countermeasures, for which flood-frequency statistics had been computed and published. In situations where a good bridge scour site did not have a streamgage located at the 
bridge, flood-frequency statistics were not computed at the scour site, therefore, the site would need to meet the drainage area ratio guidelines in the local USGS flood frequency report for adjusting the computed statistics to the bridge scour site.

3. The site had experienced a significant streamflow event since the countermeasure was installed. A significant streamflow event was generally defined as a peak streamflow corresponding to an AEP of 4 percent or less (25-year or greater recurrence interval).

Criterion 1. Although the study objective was to assess the quality and overall effectiveness of countermeasures designed to FHWA HEC 23 guidelines, some exceptions were made for sites with installed countermeasures designed according to earlier versions of FHWA guidelines. For example, site 004, Mississippi River at I-155 near Caruthersville, Missouri, was designed and built using earlier guidelines. The installed countermeasure remained structurally sound around main channel piers even though it was exposed to several substantial floods. Extensive details provided in the bridge scour countermeasure plans made it an adequate candidate for this study.

Criterion 2 . The daily and peak streamflow records for a nearby streamgage were reviewed to determine the flood history after countermeasures were installed. Historical streamflow records were obtained from the USGS National Water Information System (U.S. Geological Survey, 2016a), whereas published flood-frequency statistics were obtained from the StreamStats web application or generated using the USGS StreamStats web application (https://streamstats.usgs.gov/; U.S. Geological Survey, 2016b), and the U.S. Army Corps of Engineers River Gages website (http://rivergages.mvr.usace. army.mil/WaterControl/new/layout.cfm; U.S. Army Corps of Engineers, 2014).

Criterion 3. The 4-percent AEP was selected to ensure the installed countermeasure had been exposed to a relatively rare flood. Flood-frequency statistics downloaded from StreamStats for USGS streamgages were computed following the guidelines presented in Bulletin 17B (Interagency Advisory Committee on Water Data, 1982) and only loaded into StreamStats after they had been reviewed, approved, and published in a USGS Scientific Investigations Report for that specific state. Flood-frequency statistics were not available for a couple of sites on the Mississippi River due to complex variable flow control conditions, therefore, frequency statistics computed by the U.S.
Army Corps of Engineers (USACE) as part of their Upper Mississippi River System Flow Frequency Study (U.S. Army Corps of Engineers, 2004) were provided to the USGS to help estimate the rareness of the peak flow conditions since countermeasures were installed. At some other sites, countermeasures that experienced peak flows less than the 4-percent AEP were considered for the study if the bridges were in mountainous regions. For example, sites on a high-gradient stream that experienced streamflows less than the 4-percent AEP were determined to have a stream power and complexity of hydraulics that caused scouring comparable to that of a 4-percent AEP streamflow on a stream of lesser gradient. These sites were selected when the bankfull streamflow (typically 0.5 -percent AEP) produced scouring comparable to the 4-percent AEP streamflow given a specific set of basin characteristics (Holnbeck and McCarthy, 2009). Most of the selected sites in Montana met the bankfull streamflow criteria.

\section{Procedures for Survey Data Collection and Site Evaluation}

Traditional and GNSS survey data collection detailed bridge geometry, including pier and abutment data, river cross sections, flood plains, and countermeasures using a total station, survey grade level, or GNSS surveying techniques. Traditional survey techniques include measurements of angles, distances, and elevations from a benchmark with known horizontal position and elevation. The RTK-GNSS surveys followed the techniques and methods described in Rydlund and Densmore (2012). Digital pictures and video also were collected to document and evaluate the conditions of the bridges, abutments, stream channel, and countermeasures. More advanced techniques for topographic and bathymetric imaging using T-lidar systems for topography and MBES systems for bathymetry also were implemented and are described later in this report.

\section{Types of Countermeasures Evaluated}

The most common bridge scour countermeasure used among the sites selected for this study was riprap. Combining the use of riprap for pier scour, bank armoring, and abutment protection into one category identified 17 of the 34 bridges using riprap as the primary scour countermeasure design. Of the remaining 17 sites, 4 (all located on the East Coast) used Gabion baskets, 3 (all in Idaho) used A-Jacks, 3 used articulated concrete block, and 7 used cabled-concrete mattresses. 


\section{Riprap Countermeasure Evaluation}

The assessment of the 17 bridges in this study that utilized riprap as a scour countermeasure indicated that, in most cases, the riprap remained intact even after experiencing peak streamflows of magnitudes exceeding that of the 4-percent AEP (25-year recurrence interval) and, in some cases, streamflows exceeding the 1-percent AEP (100-year recurrence interval). At some locations, bed sediments deposited around the bridge during floods buried the installed countermeasures, making it more difficult to determine the condition of the riprap. Site 11 over the Grand River at Route A near McFall, Missouri, is an example of the challenges of determining the presence and condition of installed riprap countermeasures. The downstream side of the bridge with riprap clearly visible on the right bank, debris caught on the right pier, and a scour hole in the sediments on the downstream side of the left pier are shown in figure 3 . At this site, side-scan sonar was used to inspect the base of the riprap along the right bank (fig. 4). The sand bar on the left bank was assumed to have covered the countermeasures installed along the left bank. In addition to visual inspection of the riprap and sonar imaging to inspect underwater countermeasures, a Wolman particle count (Federal Highway Administration, 2016) also was performed to determine the size distribution based on a random sampling of the in-place riprap. The right bank riprap matrix was found to have a $\mathrm{D}_{50}$, median particle size of riprap, of 11.7 inches (fig. 5).

\section{A-Jacks and Cabled Concrete Mattress Countermeasure Evaluation}

Three of the sites studied used A-Jacks (engineered concrete armoring units designed to interlock together and reduce the forces of scour) and seven used cabled-concrete block

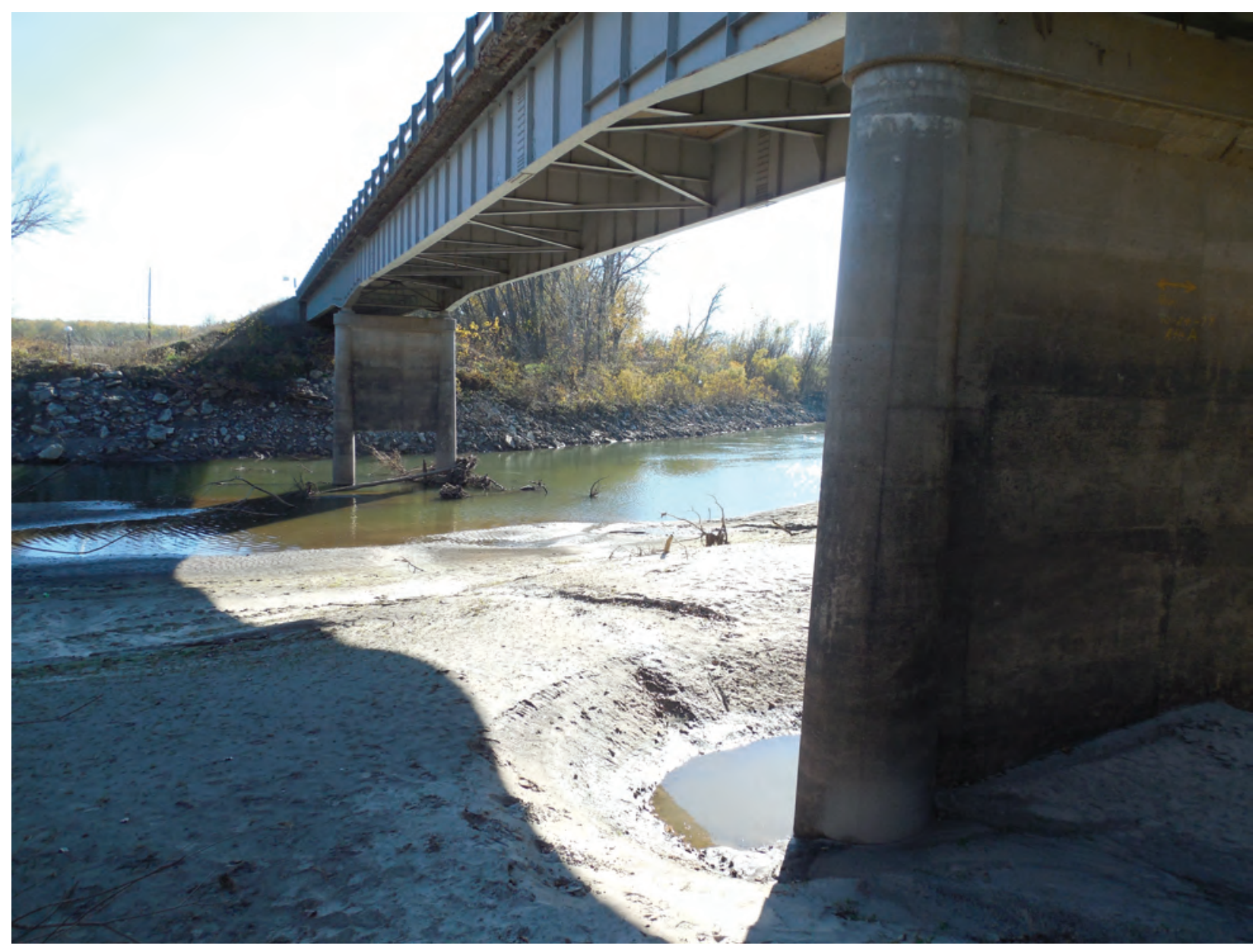

Figure 3. View of downstream side of bridge at site 011 over Grand River at Route A near McFall, Missouri, showing riprap on right bank, debris on right pier, and deposited sand bar with minor scour hole on left bank. Photograph by Richard Huizinga, U.S. Geological Survey. 


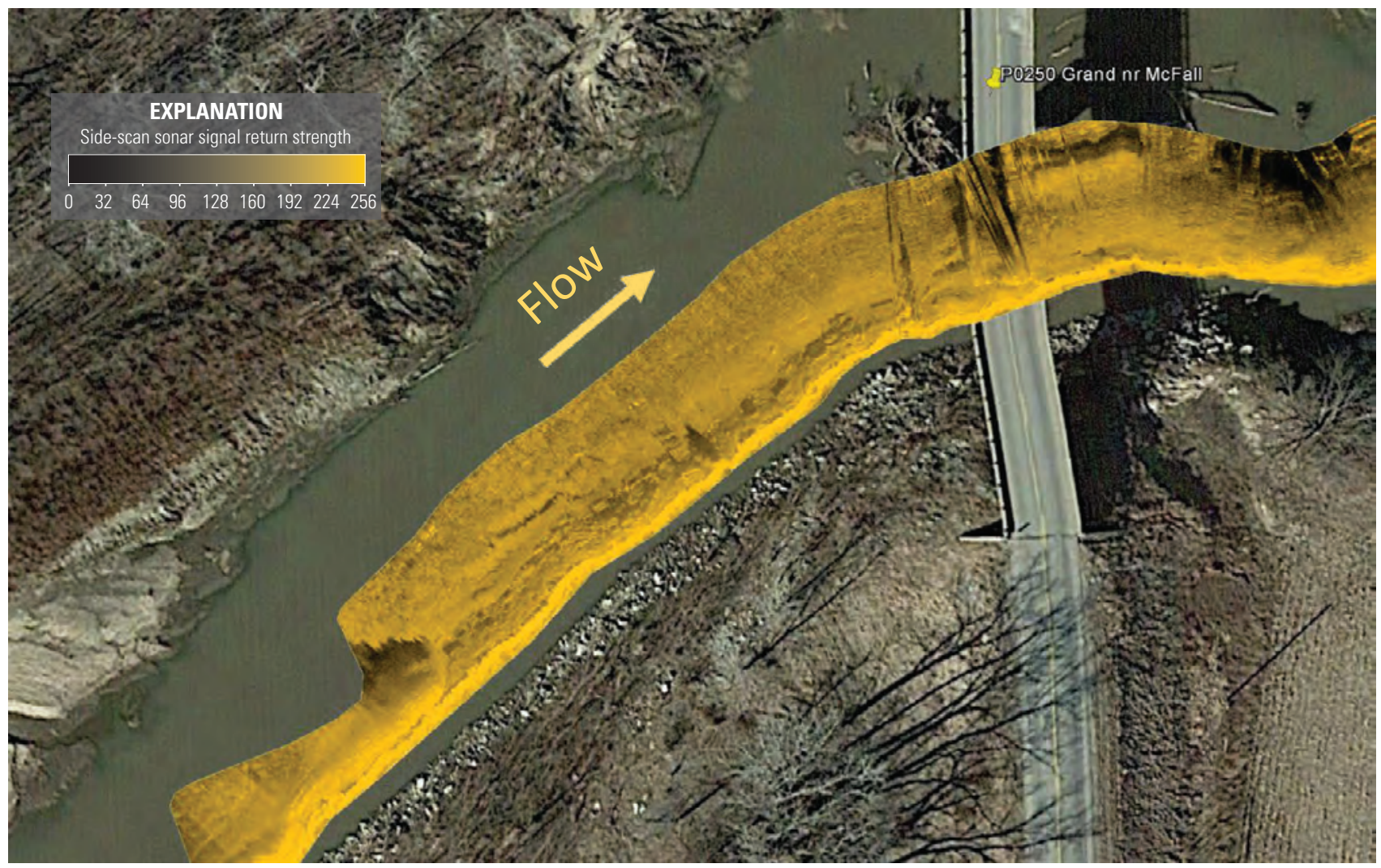

Figure 4. Side-scan sonar image of base of riprap on right bank at site 011, Grand River at Route A near McFall, Missouri.

mattresses combined with riprap. Most of these sites showed no indications of scour, although most were exposed to flooding conditions that have a statistical probability of occurrence of 4 to 10 percent each year. A-Jacks act similarly to riprap in the sense that they are still individual units that can be placed randomly to reduce scour forces, but they have a unique characteristic of being shaped like a "jack." This design feature allows them to be interlocked or banded together to form a larger mass or matrix but still be flexible enough to conform to curved channel features (fig. 6). When interlocked together as shown in figure 6, the resulting A-Jack mattress or interconnected structure is the scour countermeasure being evaluated rather than the individual A-Jack module. Study site 006, a bridge over the Snake River at Shelly West River Road near Shelly, Idaho, utilized engineered A-Jacks as a scour countermeasure along the abutment slopes and around piers to prevent erosion and scour. In this example, A-Jacks were placed in a horizontal mattress configuration along the toe of the slope to prevent slope failure and around piers 1-3 to prevent scour. The A-Jacks have been in place since 2002 and have experienced scour forces from floods that have an estimated 10-percent AEP. Although the countermeasures have not experienced flood magnitudes in excess of a 2-percent or 1-percent flood discharge, measurements made by the USGS at streamgage
13060000, Snake River near Shelley, Idaho, at flows ranging from 26,700 cubic feet per second $\left(\mathrm{ft}^{3} / \mathrm{s}\right)$ to $40,200 \mathrm{ft}^{3} / \mathrm{s}$ indicated an average channel velocity of 6-7 feet per second (ft/s). The USGS Snake River near Shelley streamgage is located about 5.7 miles (mi) upstream of site 006 , and thus the average channel velocity provides some indication about the potential velocities exerted on the countermeasures. The site inspection indicated that the A-Jacks have experienced little damage that would reduce their overall effectiveness (fig. 7). Observations from underwater videography indicate that the A-Jack modules placed along the abutments and around piers have generally remained intact and undamaged. The A-Jacks in the center of the channel (pier 2) remain mostly clear, whereas along the abutments and at piers 1 and 3, they are nearly 100 percent embedded with gravel and sediment (fig. 8).

Cabled-concrete mattresses were used as the primary scour countermeasure at seven of the sites in this report. Site 019, Gallatin River at I-90 near Manhattan, Montana, is an example of a cabled-concrete mattress that showed some signs of distress in the form of movement or slumping. The scour countermeasure plans indicated that cabledconcrete mattresses were to be installed at piers 2, 3, and 4 of Interstate 90 (eastbound and westbound) in 2006. Site inspection as part of this study indicated about $1 \mathrm{ft}$ of mattress 


\begin{tabular}{|ccccc|}
\hline $\begin{array}{c}\text { Particle } \\
\text { size } \\
\text { (inches) }\end{array}$ & $\begin{array}{c}\text { Particle } \\
\text { size range } \\
\text { (inches) }\end{array}$ & $\begin{array}{c}\text { Particle } \\
\text { count }\end{array}$ & $\begin{array}{c}\text { Cumulative } \\
\text { particle } \\
\text { count }\end{array}$ & $\begin{array}{c}\text { Cumulative } \\
\text { percent } \\
\text { smaller }\end{array}$ \\
3.00 & $\leq 3$ & 3 & 3 & 3.0 \\
4.25 & $3<x \leq 4.25$ & 5 & 8 & 8.0 \\
6.00 & $4.25<x \leq 6$ & 8 & 16 & 16.0 \\
8.50 & $6<x \leq 8.5$ & 16 & 32 & 32.0 \\
12.00 & $8.5<x \leq 12$ & 20 & 52 & 52.0 \\
17.00 & $12<x \leq 17$ & 25 & 77 & 77.0 \\
24.00 & $17<x \leq 24$ & 15 & 92 & 92.0 \\
36.00 & $24<x \leq 36$ & 7 & 99 & 99.0 \\
48.00 & $36<x \leq 48$ & 1 & 100 & 100.0 \\
68.00 & $48<x \leq 68$ & 0 & 100 & 100.0 \\
96.00 & $68<x \leq 96$ & 0 & 100 & 100.0 \\
\hline
\end{tabular}

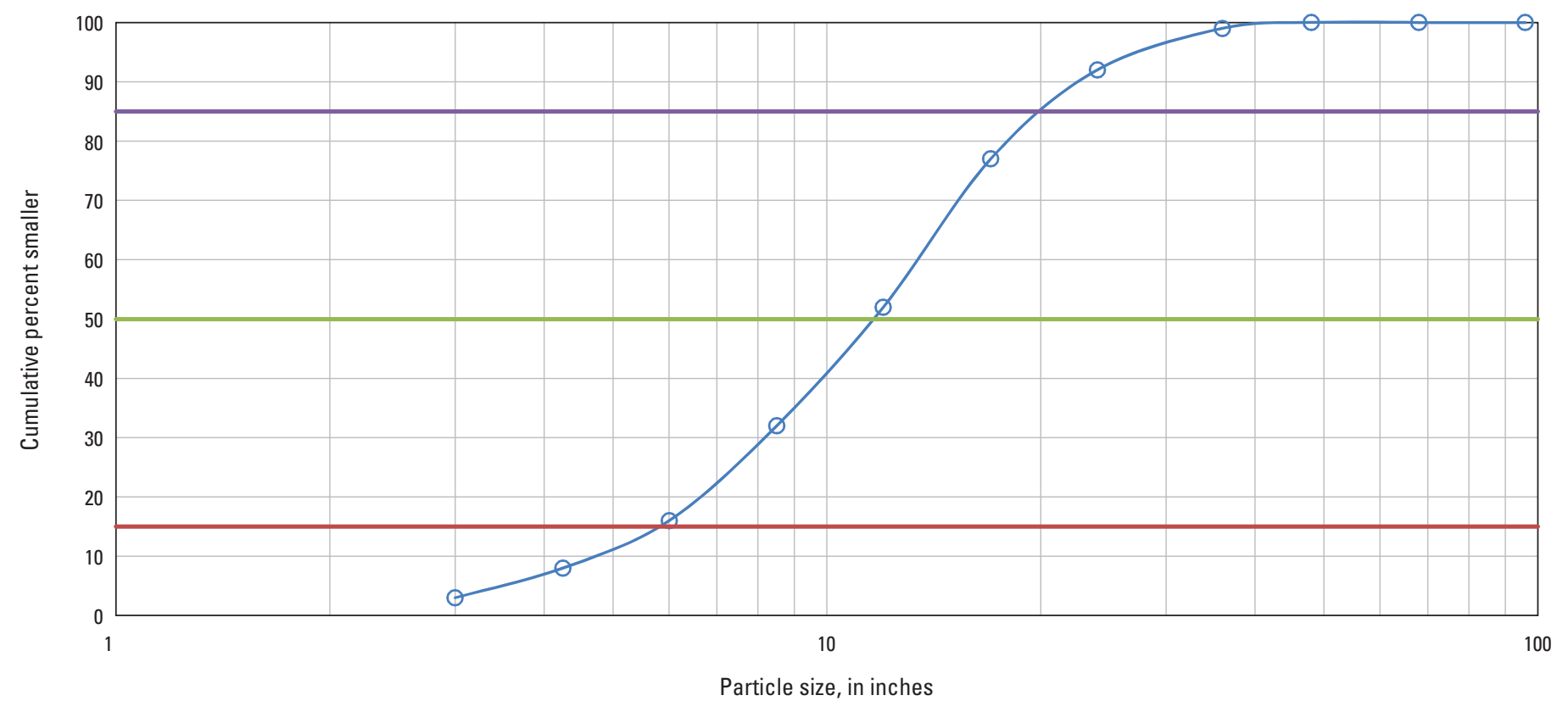

\begin{tabular}{|c|c|c|c|c|}
\hline$D_{15}$ & 5.8 & inches & $D_{85}$ & 20.7 \\
\hline$D_{50}$ & 11.7 & inches & $D_{100}$ & 48.0 \\
\hline
\end{tabular}

Figure 5. Wolman Particle Count chart for riprap on right bank at site 011, Grand River at Route A near McFall, Missouri. 


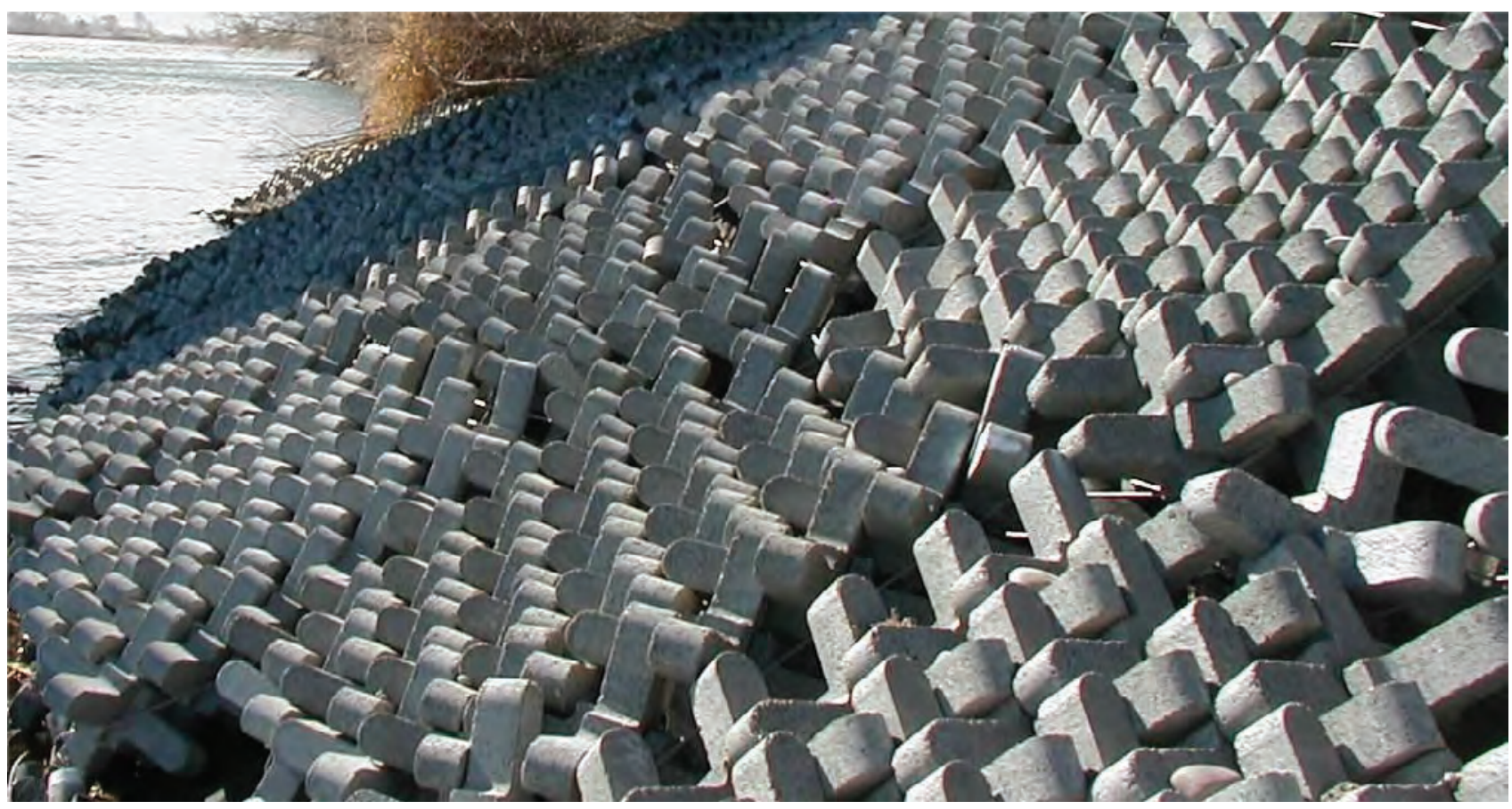

Figure 6. A-Jack countermeasures interlocked along abutment slope at site 006 on the Snake River in Idaho. Photograph by Lotwick Reese, U.S. Geological Survey.

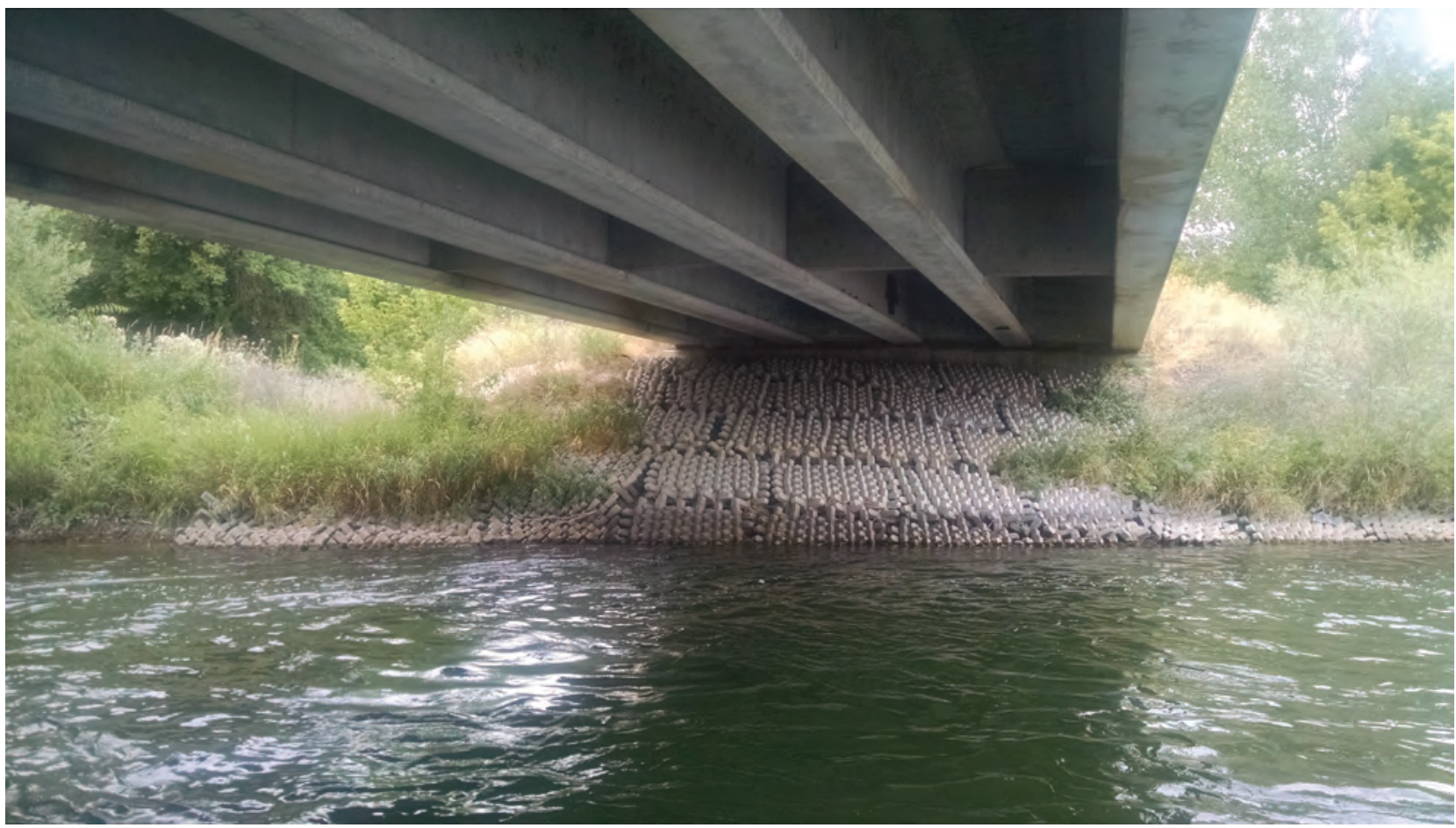

Figure 7. A-Jack countermeasures remain relatively unchanged and effective since installation in 2002 at site 006, Snake River at Shelley West River Road near Shelley, Idaho. Photograph by Daniel Ghere, Federal Highway Administration. 
$\boldsymbol{A}$

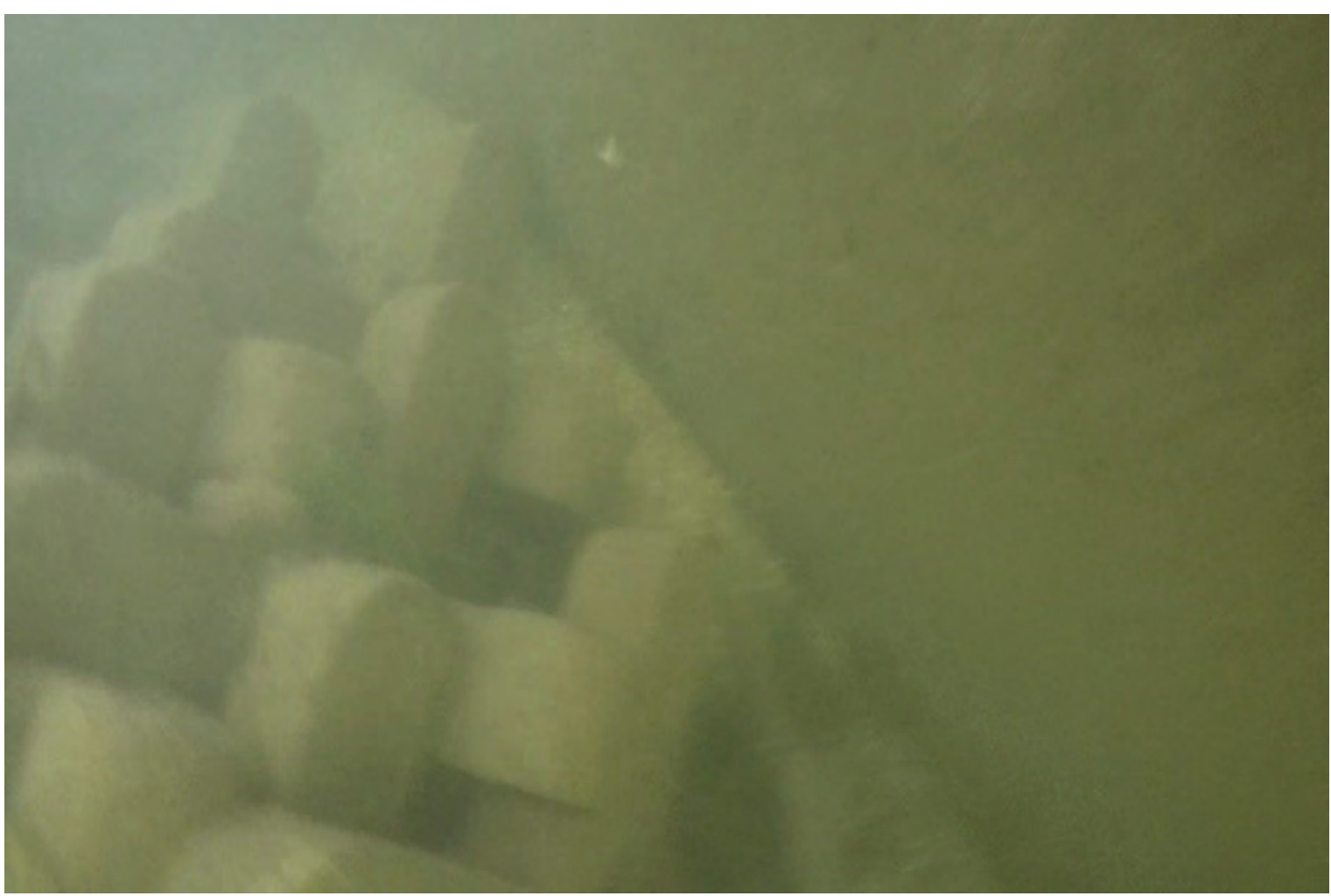

$\boldsymbol{B}$

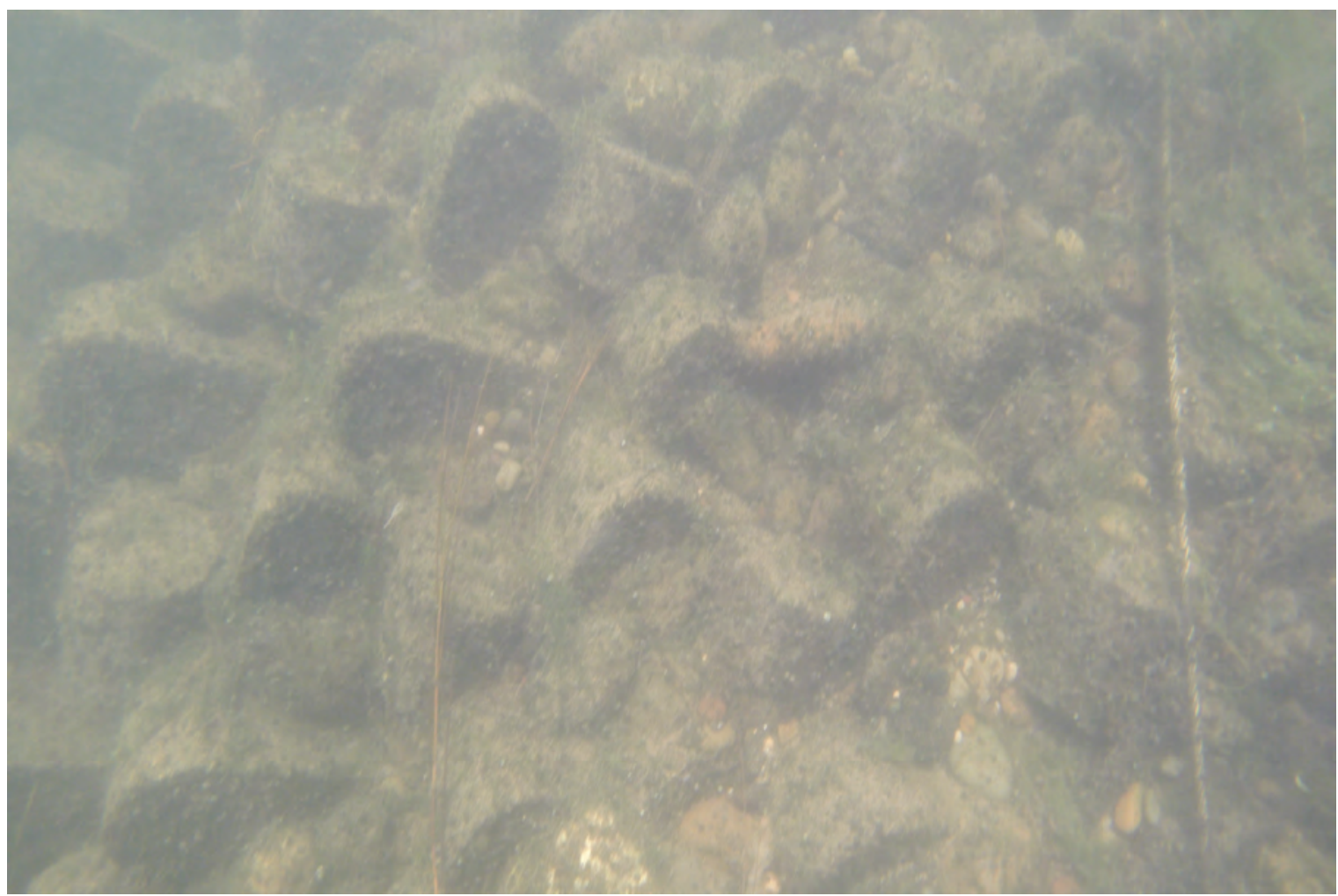

Figure 8. A, A-Jack countermeasures installed around pier 2 (center pier) at site 006 are visible with underwater videography and appear intact and effective; $B$, A-Jack countermeasures installed on toe of abutment slope and around piers 1 and 3 at site 006 along the Snake River in Idaho are mostly covered or embedded with gravel and sediment. Photographs by Ryan Fosness, U.S. Geological Survey. 
separation in the longitudinal direction and some slumping towards the center of the channel (fig. 9).

\section{Gabion Baskets and Articulating Concrete Block Countermeasure Evaluation}

At four of the study sites, Gabion baskets were installed as the primary scour countermeasure. Two of the sites were in South Carolina, one was in Florida, and one was in New Jersey. Most sites showed minimal, if any, scour, but shifting of the baskets was noted at several sites. Site 028, a bridge over Smith Branch along Clement Road in Columbia, South Carolina, is an example of a site that utilized an extensive layout of Gabion baskets around the bridge and across the channel in the approach to and exit from the bridge (fig. 10). The Gabion baskets at this site were installed in 1998, and major floods that exceeded the 1-percent AEP were documented by the USGS in July 2013, October 2015, and August 2016. Site inspection during this study indicated that the Gabion baskets generally showed shifting and slumping in the vicinity of the bridge, but some areas experienced more extensive damage. Part of the original Gabion baskets were lifted and folded downstream over themselves during a past flood event, when scour along the edge of the Gabion baskets allowed flood waters to force the baskets downstream resulting in the damaged countermeasures shown in figure 10. A sanitary sewer line is present immediately upstream of the mattress along the stream bottom that may have complicated the flow hydraulics in this area (fig. 11). Articulated concrete block (ACB) countermeasures were installed at site 013, Byram River at Sherwood Ave. at Greenwich, Connecticut; site 015, Bitterroot River at Bell Crossing near Victor, Montana; and site 034, Saddle River at NJ-17 at Ridgewood, New Jersey. The evaluation of sites 013 and 034 showed the countermeasures were generally intact. The ACBs were covered with sediment in some areas but remained generally visible, but some notes indicated that some blocks had begun to separate near the edges. The ACBs at site 015 were submerged and not visible at the time of the site evaluation, but riprap along the banks was noted as being intact without signs of failure. Additional data about this site and others used in this study can be found in two USGS Open-File Reports (Dudunake and others, 2017, 2019) and the companion data releases (Dudunake, 2017, 2019).

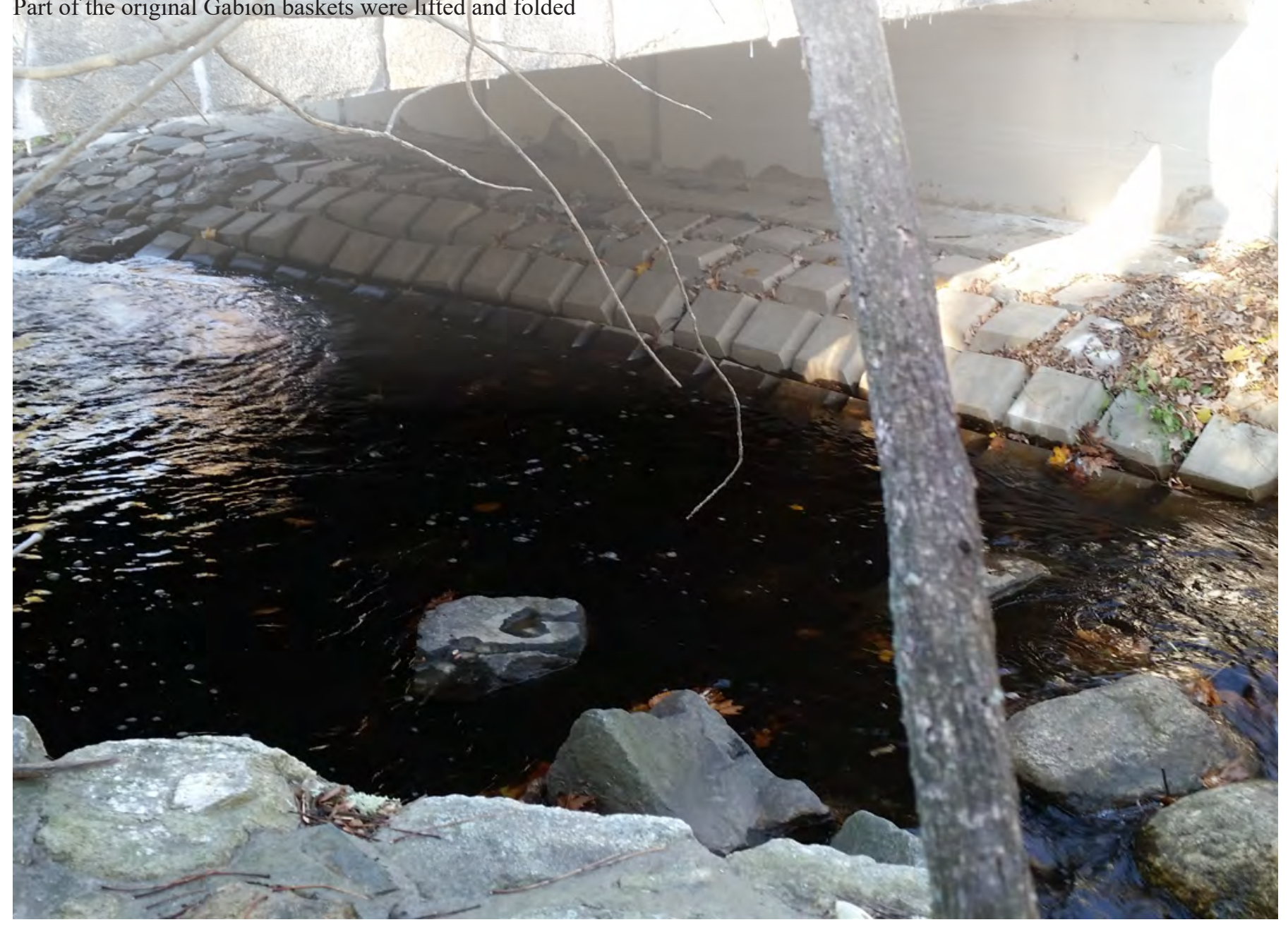

Photograph of articulated concrete block countermeasures along the banks of the Saddle River at Ridgewood, New Jersey. Photograph by Jason Shvanda, U.S. Geological Survey. 
$\boldsymbol{A}$

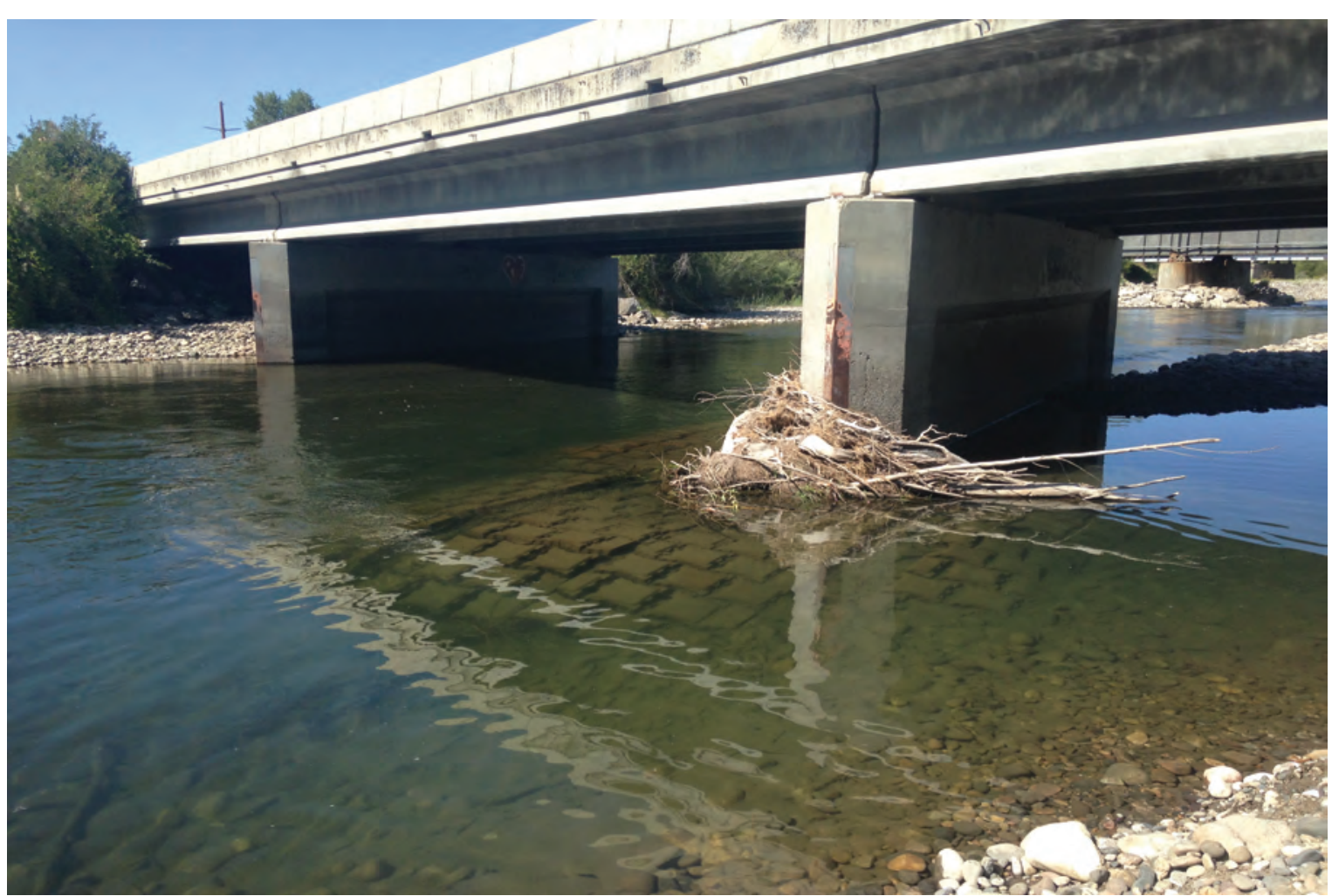

B

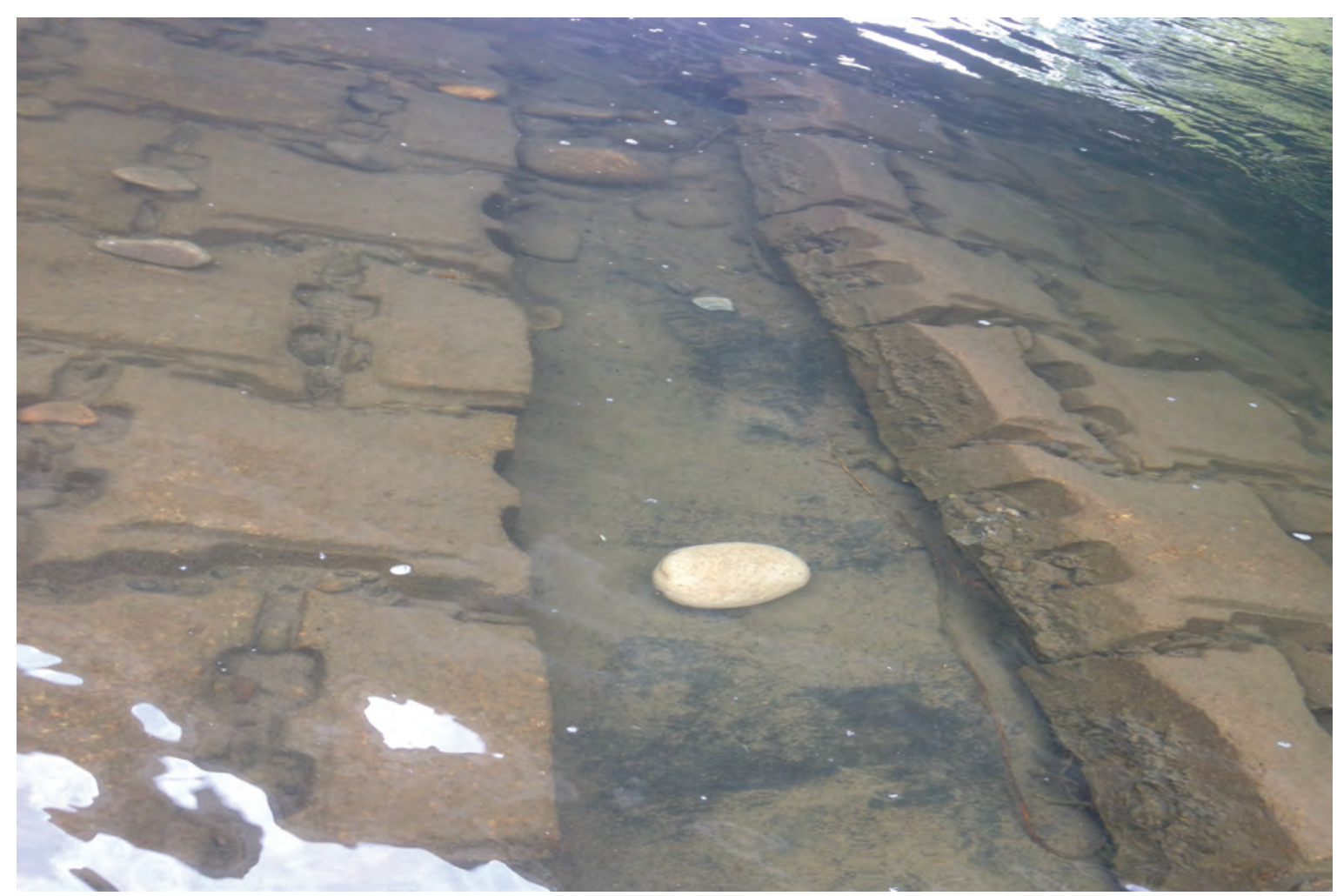

Figure 9. Distressed cabled-concrete mattress countermeasures installed at site 019, Gallatin River at I-90 near Manhattan, Montana. $A$, looking upstream at I-90 bridge towards left bank at distressed countermeasures; $B$, at upstream side of bridge looking down at distressed countermeasure showing large separation to the right towards main channel. Photographs by Stephen Holnbeck, U.S. Geological Survey. 
$\boldsymbol{A}$

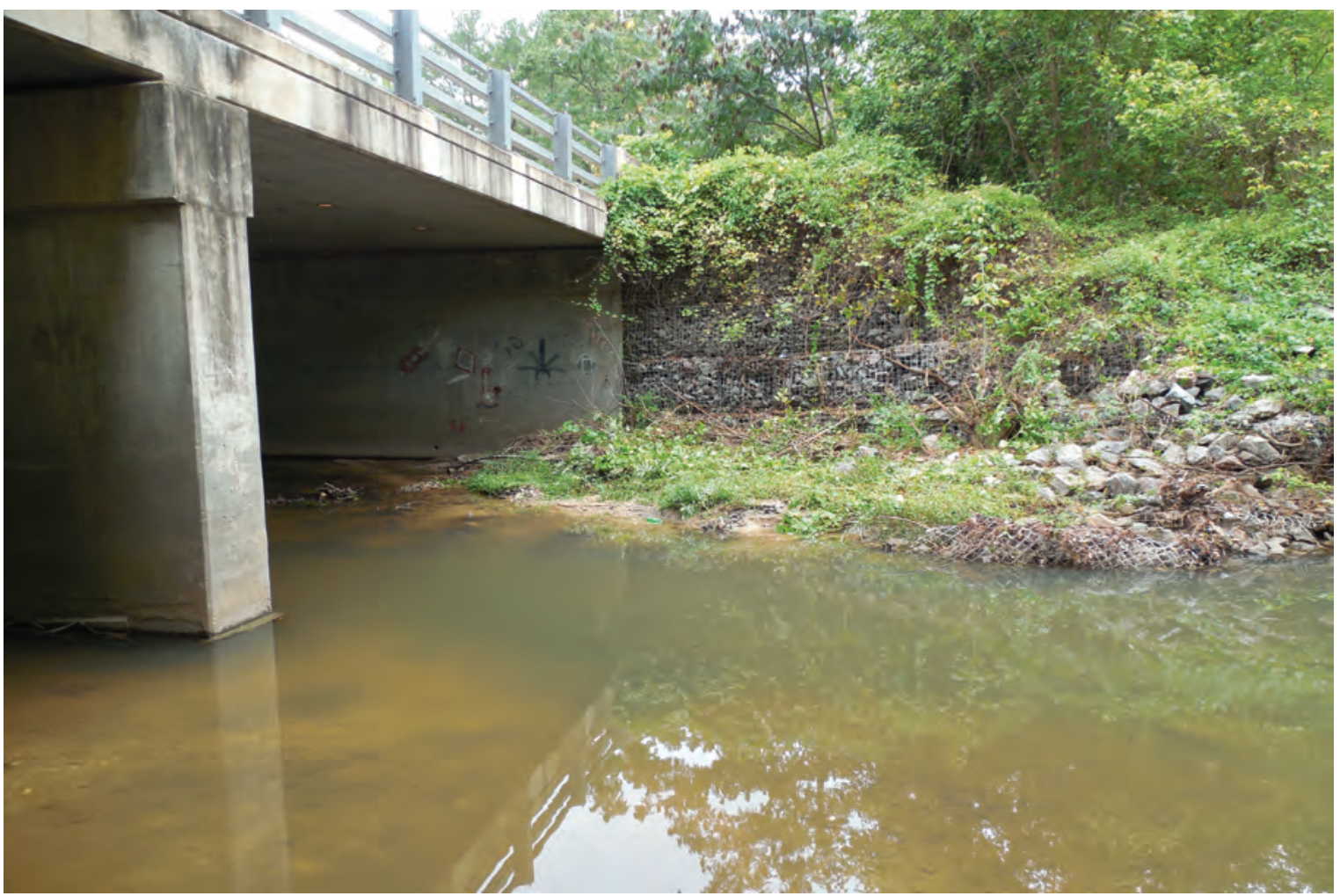

\section{$\boldsymbol{B}$}

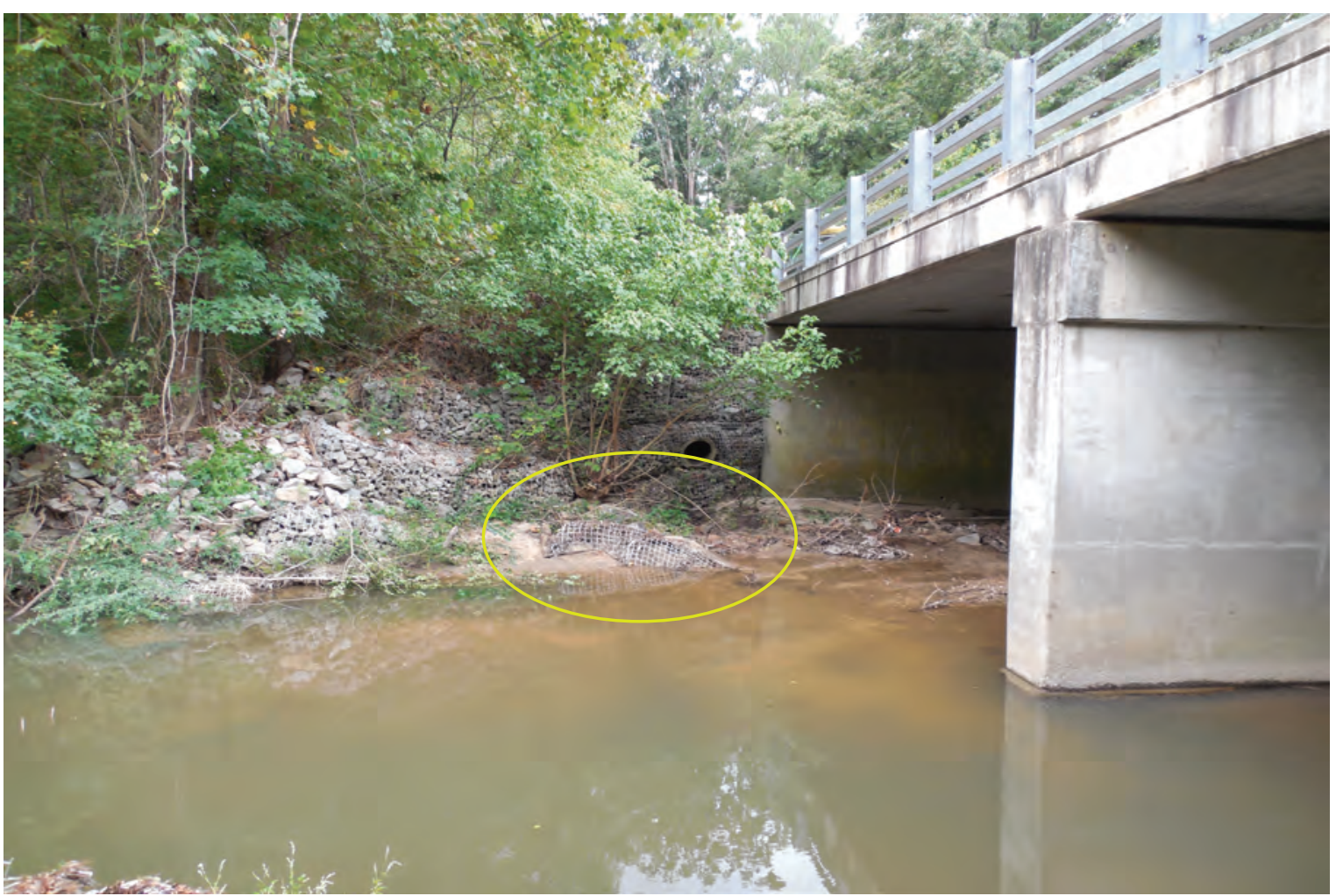

Figure 10. A, Gabion baskets installed around upstream right side of Site 028, a bridge over Smith Branch along Clement Road in Columbia, South Carolina, showing some signs of shifting near toe of embankment; $B$, Gabion baskets installed around upstream left side of bridge over Smith Branch showing more signs of shifting and the edge of the baskets was scoured, lifted, and folded over itself. Photographs by Richard Huizinga, U.S. Geological Survey. 


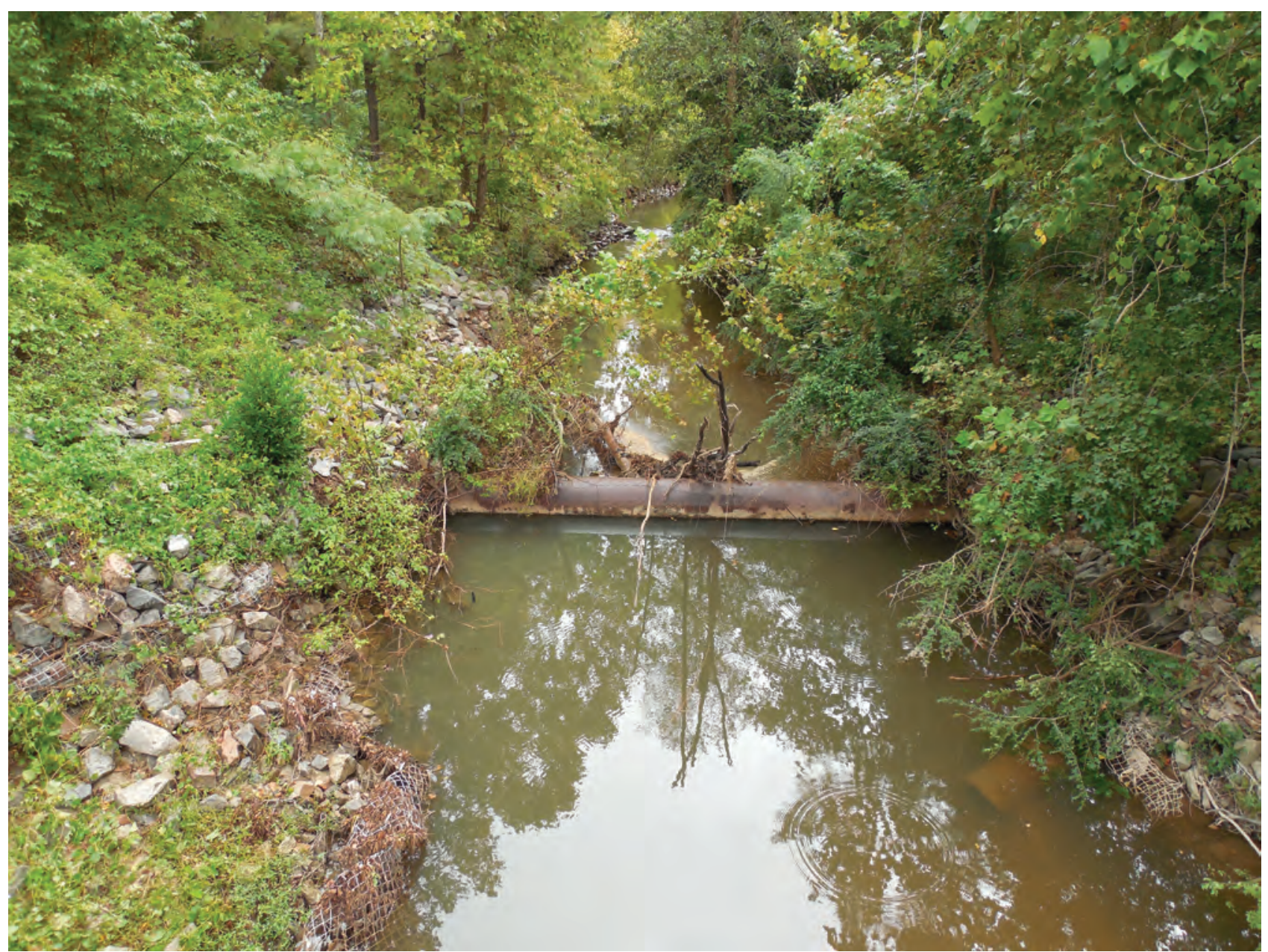

Figure 11. Sanitary sewer pipe line across Smith Branch, site 028, Columbia, South Carolina, just upstream of original upstream extent of Gabion mattress countermeasure installation. Photograph by Richard Huizinga, U.S. Geological Survey.

\section{Procedures for Bathymetric and Topographic Data Collection and Processing}

The bathymetric and topographic data at each of the sites in Categories 1 and 2 were collected using a high-resolution marine-based mobile mapping system. Topographic data at several other sites were collected using a T-lidar system. A marine-based mobile mapping system is an integration of several individual components: a MBES, a T-lidar system, an inertial navigation system (INS), and a data-collection computer. A brief description of the equipment follows; more in-depth descriptions of the various system components and types of methods used in this study are available in reports by Huizinga (2010), Huizinga and others (2010), Lee (2013), Densmore and others (2013), Kimbrow and Lee (2013), and Huizinga and Wagner (2019).

\section{Equipment}

Bathymetric data were collected using four different MBES systems: the R2Sonic 2024 (site 001), the Teledyne RESON SeaBat 7125-SV2 (sites 003, 004, and 007), the Teledyne Odom ES3 240kHz (sites 005 and 006), and the Norbit iWBMSh (site 030). The MBES data generally were collected in longitudinal transects with approximately 50-percent overlap of subsequent survey swaths to ensure complete coverage of the channel bed and to minimize sonic "shadows." Substantial overlap was achieved for many of the surveyed swaths, except in wide, shallow areas near the channel banks or near spur dikes, other in-flow structures, debris rafts, or moored barges. At several sites, the areas near the bridge piers and along the banks also were surveyed in an upstream direction with the MBES head tilted (mechanically or electronically) at 30 degrees to either port or starboard to increase the acquisition of bathymetric data in the shallow areas, and higher on 
the banks and the sides of the piers. To limit potential damage to the MBES head, most shallow areas having water less than approximately $6 \mathrm{ft}$ deep were not surveyed.

Topographic data of the above-water part of several Category 1 and 2 sites (sites 001,003,004, and 007) were collected using a vessel-mounted T-lidar system (fig. 12), a Teledyne-Optech ILRIS High Density (HD) Enhanced Range (ER) laser scanner (Teledyne-Optech, 2012). The topographic data were collected along a single vertical line in the field of view of the instrument, and data essentially were collected in a vertical "fan" along that line as the survey vessel moved. Topographic data were obtained along each bank, along the upstream and downstream faces of the bridge, and on both sides of each pier at the site of interest, often in multiple passes with different aspect angles and speeds to capture data from multiple directions in an attempt to maximize the coverage.

The bathymetric and topographic data collected with the MBES and T-lidar components of the marine-based mobile mapping system were accurately represented in three-dimensional space by use of an INS. The INS that was used in surveys of Category 1 and 2 sites was the Applanix Position Orientation Solution for Marine Vessels (POS MV) system (Applanix Corporation, 2006). The INS uses an inertial measurement unit (IMU) coupled with two GNSS antennae to provide position in three-dimensional space and measure the heave, pitch, roll, and heading of the vessel and, thereby, the MBES and T-lidar units.

\section{Processing}

The navigation information from the INS was postprocessed using the POS-Pac Mobile Mapping Suite (MMS) software (Applanix Corporation, 2009) to mitigate the effects of degraded positional accuracy of the vessel while near or under a bridge. POS-Pac MMS provides tools to identify and compensate for sensor and environmental errors and computes an optimally blended navigation solution from the GNSS and IMU raw data. The blended navigation solution (called a "smoothed best estimate of trajectory" or "SBET" file) generated by post-processing the navigation data provides centimeter- to decimeter-level positional accuracy and was applied to the survey at a given bridge to improve the real-time position information of the survey and minimize the effects of the GNSS outages while surveying under the bridge.

The bathymetric data from the MBES and INS components were processed and integrated into cohesive datasets for cleanup and visualization. A computer on the survey vessel ran the HYPACK/HYSWEEP data acquisition software (HYPACK, Inc., 2015) that was used to prepare for the bathymetric and topographic surveys and collect the survey data. After completing the surveys, the acquired bathymetric data were further processed to remove data spikes and other spurious points in the multibeam swath trace, georeferenced using the navigation and position solution data from the SBET file from POS-Pac MMS, and visualized in HYPACK/HYSWEEP as a triangulated irregular network surface or a point cloud.

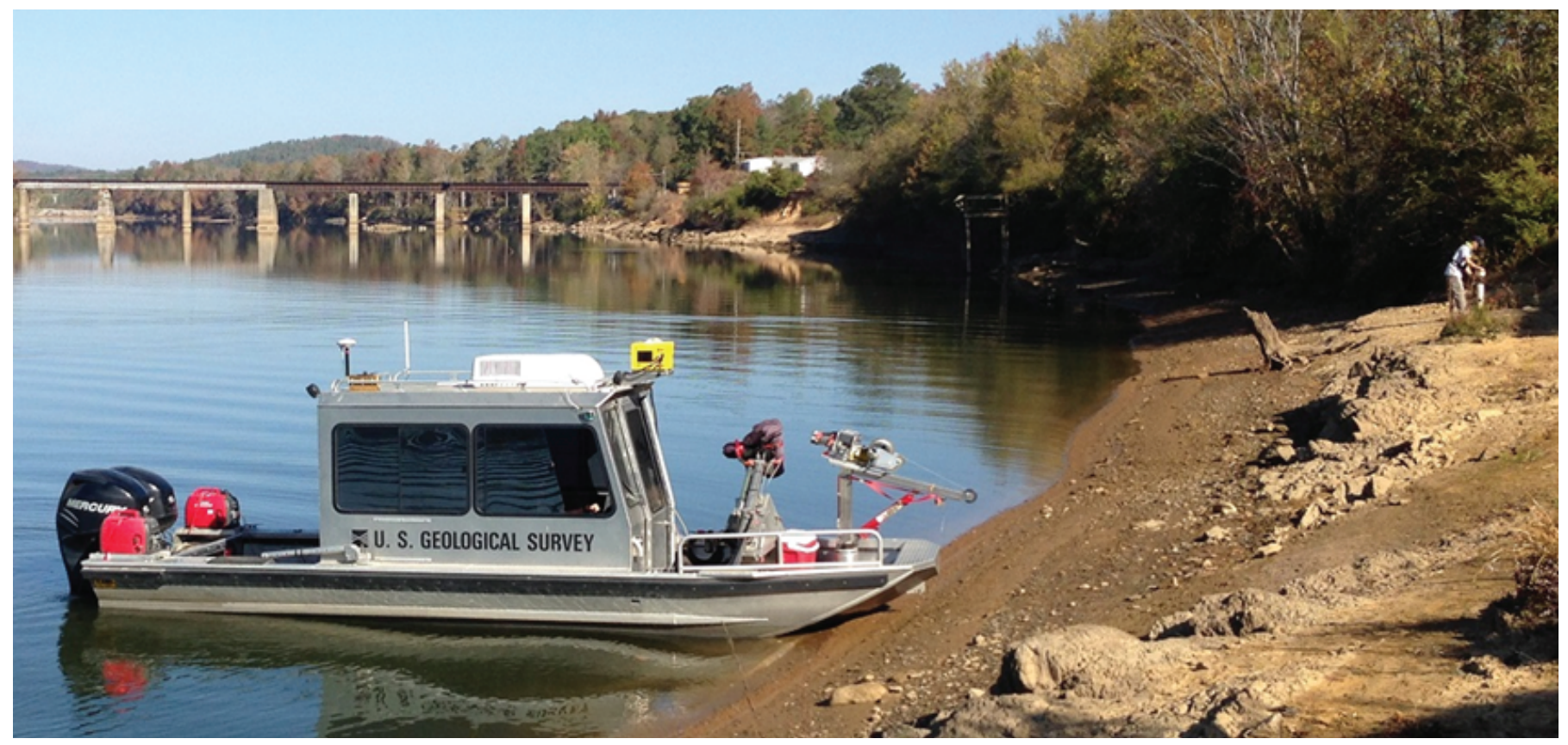

Figure 12. Vessel mounted Teledyne-Optech ILRIS High Density (HD) Enhanced Range (ER) laser scanner. Photograph by Richard Huizinga, U.S. Geological Survey. 
The edited bathymetric data were projected to a three-dimensional grid at a resolution of $1.64 \mathrm{ft}(0.5$-meter) using the Combined Uncertainty Bathymetry Estimator (CUBE) method (Calder and Mayer, 2003), as implemented in the MB-MAX processing package of the HYPACK/HYSWEEP software (HYPACK, Inc., 2015). Uncertainty in the overall bathymetric survey was estimated by computing the total propagated uncertainty (TPU) for each survey grid cell in the bathymetric surface of each survey area, also using the CUBE method. The bathymetric data near piers and scour countermeasures were output without any data reduction to provide increased resolution near these features of interest. The final reduced or unreduced bathymetric data were output to a space-delimited $\mathrm{XYZ}$ data file and were compiled and included with metadata in Dudunake (2017, 2019).

Similarly, the topographic data from the T-lidar and INS components were parsed, processed, and integrated into cohesive datasets for visualization and cleanup. The T-lidar data were parsed in the Teledyne-Optech Parser executable to apply necessary offset and orientation parameters, and to georeference the data using the navigation and position solution data from the SBET file from POS-Pac MMS. The T-lidar data were output to multiple XYZ datasets with intensity, one for each survey line. The various XYZ files for a given survey were combined into a single topographic dataset and visualized in the PolyWorks IM-Align and IM-Survey software packages and were cleaned of spurious points and reflections off the water. The processed and edited data were output to a space-delimited XYZ dataset with intensity, one file for each site, and are included with metadata in the data releases (Dudunake, 2017, 2019).

\section{Error Estimation}

The errors associated with the collection of bathymetric and topographic data can be classified as systematic or random. Systematic errors are those that can be measured or modeled through calibration (Byrnes and others, 2002). Random errors are a result of the limitations of the measuring device and an inability to perfectly model the systematic errors. Because the channel bed generally was not visible in the bathymetric data collection, random errors associated with the limitations of the MBES are difficult to quantify. To minimize these errors, quality assurance assessments were performed or verified in real time during the surveys. A series of patch tests was performed to measure variations in the orientation and timing of the MBES with respect to the INS and real-world coordinates (HYPACK, Inc., 2015). The patch tests are used to determine timing offsets caused by latency between the MBES and the INS, and angular offsets to roll (longitudinal axis), pitch (lateral axis), and yaw (rotation around vertical axis) caused by the alignment of the transducer head. The results of these patch tests were accounted for when processing the bathymetric data with the HYPACK/HYSWEEP software.
Similarly, a boresight calibration test is used to measure variations in the orientation of the T-lidar unit with respect to the INS and real-world coordinates (Teledyne-Optech, 2012). The angular offsets to roll, pitch, and yaw caused by the alignment of the T-lidar unit and the INS on the survey vessel, as well as the positional (lever arm) offsets of the T-lidar with relation to the INS were determined for each scan direction (port or starboard) of the T-lidar unit on each vessel. The lever arm and angular offsets determined in the boresight calibration test were applied when parsing and processing the data collected from a given T-lidar survey.

\section{Initial Imaging}

Bathymetric data were output with no data reduction near the principal features of interest in the study, namely the scour countermeasures. The higher-resolution data near the countermeasures provide a more accurate image of the countermeasure condition, compared to the designed countermeasure. The data collected at the first Category 1 and 2 site was used to develop data-collection procedures that were applied at subsequent sites. At site 001 on the Apalachicola River near Chattahoochee, Florida, the flow conditions were nearly ideal for high-resolution bathymetric data collection, since the river is relatively wide in a tidal zone with low-velocity flow at the time of the survey. The survey vessel was able to maintain a low rate of speed while maintaining good navigation control, particularly near the bridge piers and countermeasures. Multiple survey passes were made on both sides of each pier, using different settings and swath angles of the MBES to collect data and characterize the condition of the countermeasures near these piers. These multiple passes would, in theory, provide high resolution of the countermeasures when overlain.

The defined data-collection methods were generally followed at the subsequent Category 1 and 2 sites. However, guidance on the speed of the survey vessel had not been specified at the first site; therefore, data collected at subsequent sites was controlled and varied according to local conditions. The subsequent sites were on the Mississippi and Wabash Rivers, each subject to substantially higher flow velocities than those on the Apalachicola River, and data collection was further complicated by the presence of debris rafts and other navigational hazards, particularly near the piers. Nevertheless, multiple survey passes were collected over the countermeasures, with the intent of overlaying the data if needed.

The resolution of the resulting datasets was not sufficient to classify the size of individual riprap stones, which was necessary to determine the particle-size distribution of the in situ countermeasures. Whereas the data initially appeared to be of sufficiently high resolution to accomplish this, closer examination of the data implied the distance between points was too large to accurately resolve the various sizes of the stone (fig. 13A, original image resolution). Furthermore, it was discovered that because of minor positional variations in 


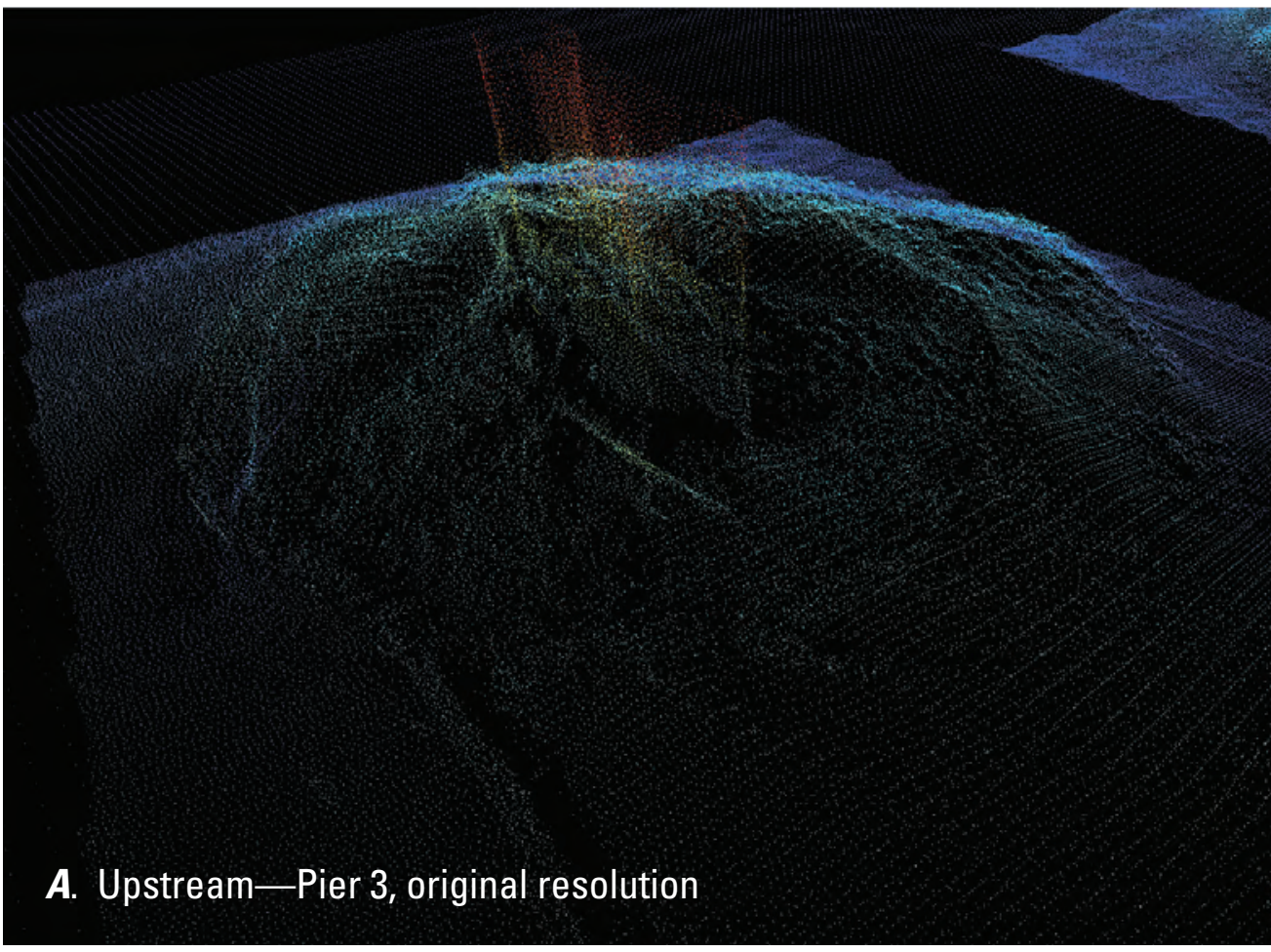

\section{EXPLANATION}

Channel-bed elevation, in meters above North American Vertical Datum of 1988
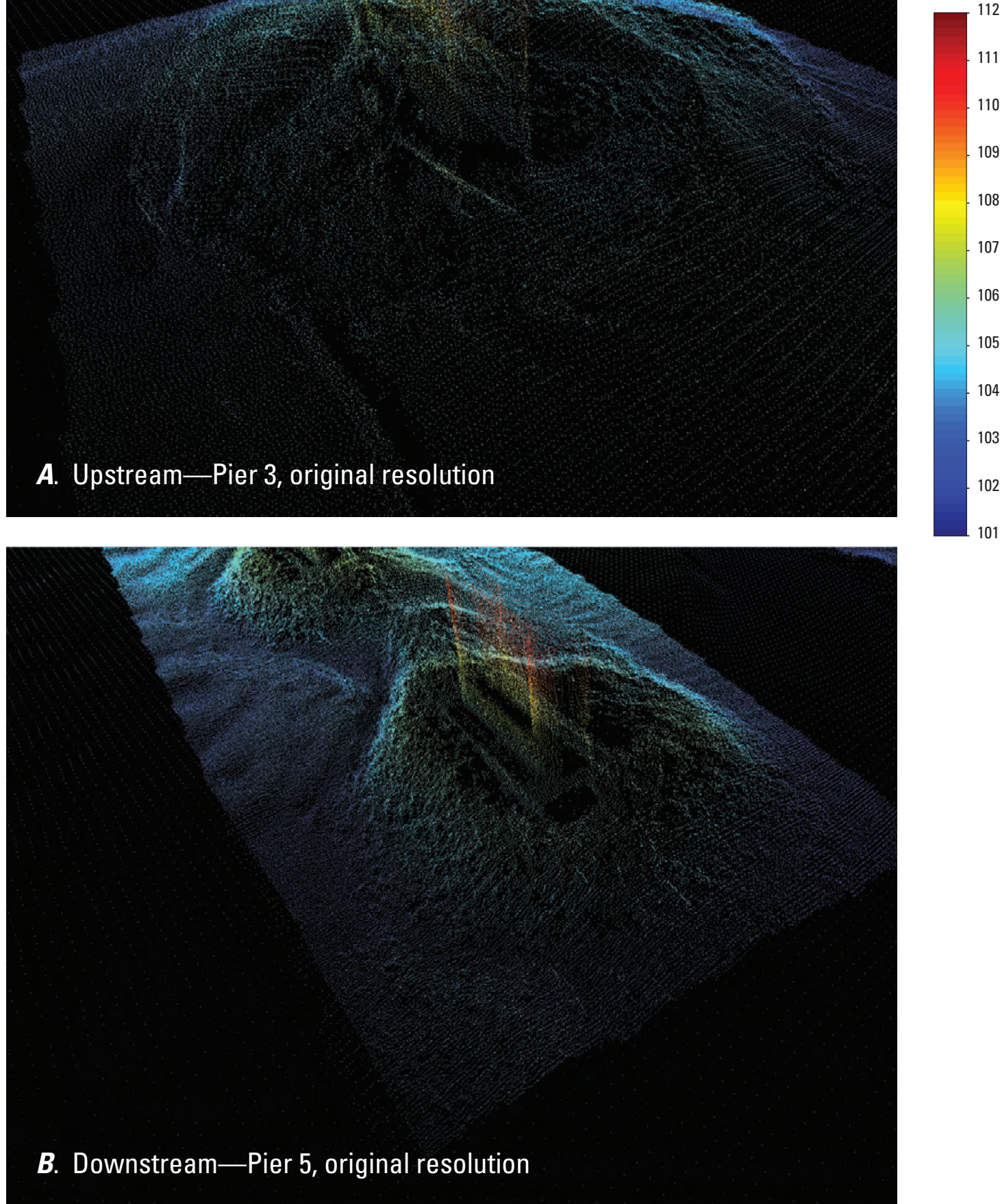

101

Figure 13. Oblique view (from downstream right [southwest]) of the bathymetric survey of the scour countermeasures near $A$, upstream pier 3, and $B$, downstream pier 5 of site 007 at structures 097-0003/0004 on Interstate 64 over the Wabash River near Grayville, Illinois, showing original resolution data from the May 2, 2016 survey. 
the data in each pass, combining multiple survey passes led to "fuzziness" in the resultant combined point cloud data. It was also determined that although the positional accuracy of the MBES data was generally good, errors resulting from GNSS signal outages under the bridge led to minor discrepancies in position of the vessel and the resultant MBES data. Therefore, better methods for collecting high-resolution MBES images of the scour countermeasures were pursued.

\section{High-Resolution Data Collection and Processing}

Once it had been determined that the resolution of most of the data collected with the MBES was insufficient to determine the riprap particle-size distribution, the methods by which MBES data were obtained were re-evaluated. The desired resolution was a nominal point distance of 0.02 meter $(\mathrm{m})$ that could be achieved without requiring multiple survey passes. It was determined that the Apalachicola River data were close to this resolution in the original survey, so the unreduced data near the piers were simply saved to individual files rather than as a combined dataset of overlain lines. However, the other Category 1 and 2 sites required a modified method of data collection.

Trigonometry and beam configuration were evaluated to achieve the desired resolution between points in each ping. (A "ping" as used herein is a short acoustic pulse transmitted into the water from the MBES). The distance between points in the MBES swath (in a given ping) was computed based on the swath angle, the distance to the channel bed, and the number of discrete points (512) in each ping within the swath. The swath angle could then be adjusted to give a nominal distance between points of $0.02 \mathrm{~m}$, depending on the depth of the water over the countermeasure during the survey.

The distance between pings along the survey line was more difficult to control because it is controlled by the ping rate of the MBES (the number of pings per second) and the forward speed of the vessel over ground (distance traveled per second). The ping rate, in turn, is controlled by the ping pulse length and range settings of the MBES. If the pulse length is set too high, the MBES is required to "listen" longer for the full pulse of the return ping; therefore, it was beneficial to set the pulse length to the minimum value. However, the range setting is dependent on the depth of the channel; as the depth increases, the range must be increased accordingly to capture data in the entire swath angle, which decreases the ping rate as the MBES is again required to "listen" longer for the return ping.

The forward speed of the vessel was then adjusted according to the achievable ping rate to maintain a nominal longitudinal point spacing of $0.02 \mathrm{~m}$. Given the depth typically observed at the Mississippi River (10-15 m), a swath angle of 40-60 degrees and a range setting of 15-20 m would result in a ping rate of around 20 pings per second (20 hertz, or Hz). At this ping rate, a forward speed of approximately 1 knot ( 0.51 meter per second, or $\mathrm{m} / \mathrm{s}$ ) would result in the desired resolution. A great deal of caution was required to navigate the survey vessel near the bridge piers at such a low speed, as turbulence near the pier was often substantial. Nonetheless, by use of this approach, a single pass of high-resolution data was able to be collected for the scour countermeasures on either side of each pier at sites 003, 004, and 007.

The data from the high-resolution collection efforts were processed in the same way as the original data (as detailed in the "Processing" section above). In addition to the highresolution data near the piers and scour countermeasures, a survey of the whole site was conducted, as the channel-bed conditions during the high-resolution survey were different from those during the original survey. The overall survey data were processed and reduced to a resolution of $1.64 \mathrm{ft}(0.5 \mathrm{~m})$ using the CUBE method as with the original survey, and uncertainty in the overall bathymetric survey was estimated by computing the TPU for each survey grid cell in the bathymetric surface of each survey area, also using the CUBE method. The high-resolution bathymetric data were output without any data reduction to provide maximum resolution near features of interest. The final reduced or unreduced bathymetric data were output to a space-delimited XYZ file and were compiled and included with metadata in data releases by Dudunake (2017, 2019) along with the original data.

Using the modified data-collection procedures, highresolution data were collected at the Category 1 and 2 sites. A sample of the original and high-resolution data is shown in figure 14. Using similar processes, high-resolution bathymetric data also were collected at site 030 , one of the Category 3 and 4 sites where one of the scour countermeasures was submerged riprap near the piers.

\section{Additional Data Collection with Tripod-Mounted Terrestrial Lidar Systems}

At several of the Category 1 through 7 sites, the condition of the above-water part of the surveyed reach at each site was determined using a tripod-mounted T-lidar system. The same Teledyne-Optech ILRIS HD ER instrument that was operated in motion-compensated mode to survey the Category 1 and 2 sites also was used to survey the Category 3 and 4 sites in Missouri, but was mounted to a tripod and equipped with a pan/tilt base, allowing the scanner's standard 40 x 40 degree field of view to be rotated 360 degrees and also tilted vertically, if necessary (fig. 15A). Topographic data were obtained by rotating the T-lidar unit in discrete steps on the pan/tilt base at several tripod setup points in the surveyed reach. Reference spheres were placed throughout the reach in the field of view of the lidar unit at each tripod setup to assist in aligning each scan with the others. The locations of these spheres were also surveyed using GNSS to georeference the survey.

At the three Category 3 and 4 sites in Iowa, T-lidar data were collected using a FARO Focus3D X130 laser scanner (fig. 15B). The FARO scanner is substantially smaller than the ILRIS HD ER with a more limited range; however, it 

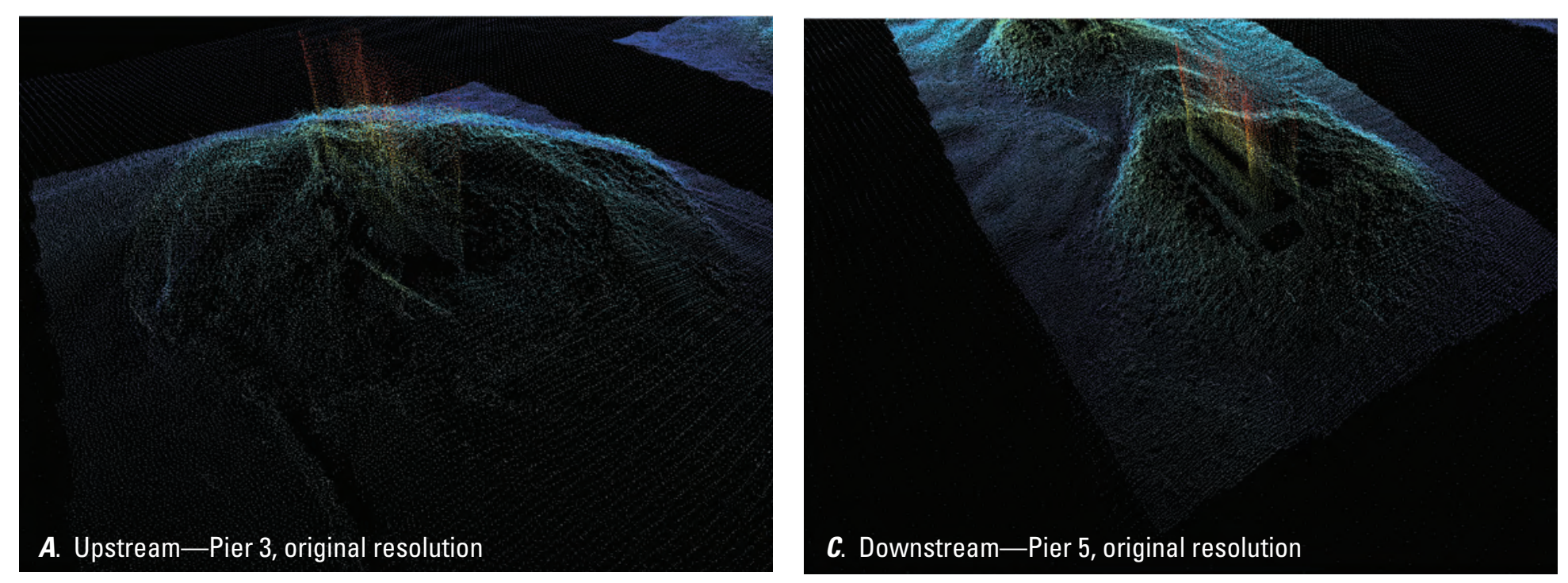

\section{EXPLANATION}

Channel-bed elevation, in meters above North American Vertical Datum of 1998

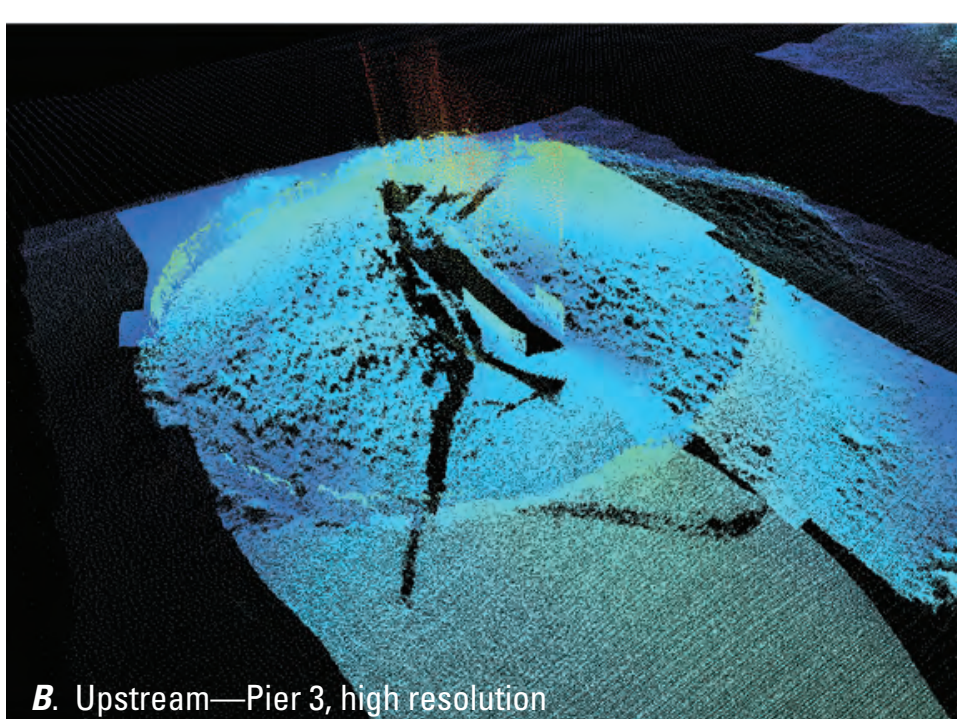

Figure 14. Oblique view (from downstream right [southwest]) of the bathymetric survey of the scour countermeasures at site 007 of structures 097-0003/0004 on Interstate 64 over the Wabash River near Grayville, Illinois, near upstream pier 3 showing $A$, original resolution data from the May 2, 2016 survey, and $B$, high-resolution data from the August 27, 2018 survey, and near downstream pier 5 showing $C$, original resolution data from the May 2, 2016 survey, and $D$, high-resolution data from the August 27, 2018 survey. 

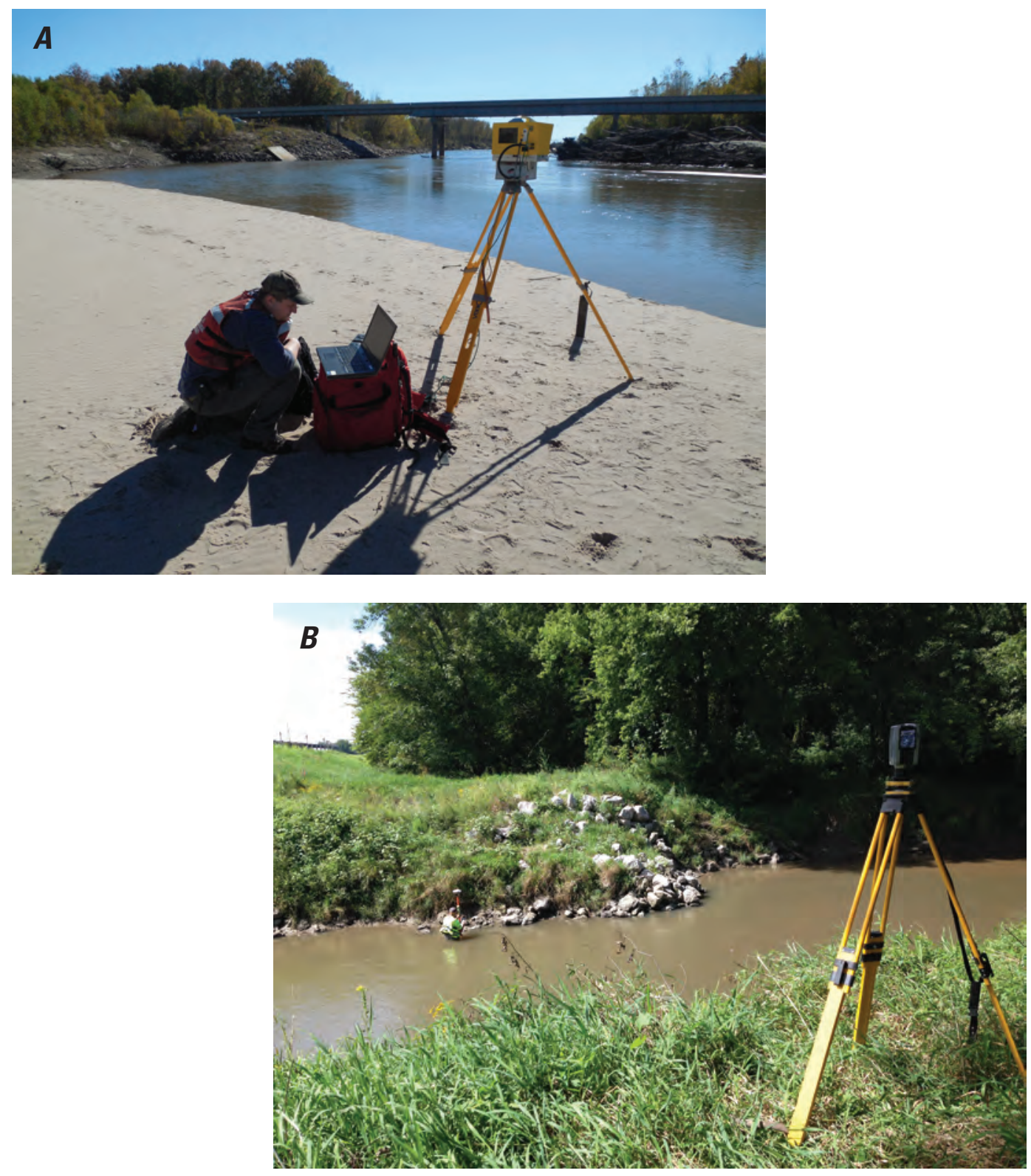

Figure 15. A, Teledyne-Optech ILRIS High Density (HD) Enhanced Range (ER) laser scanner, $B$, FARO Focus 3D X130 laser scanner setup, and C, Trimble VX Stationary three-dimensional single-laser scanner, all shown mounted on tripods. Photographs $15 A$ and $15 B$ by Richard Huizinga, U.S. Geological Survey. Photograph $15 C$ by Ryan Fosness, U.S. Geological Survey.

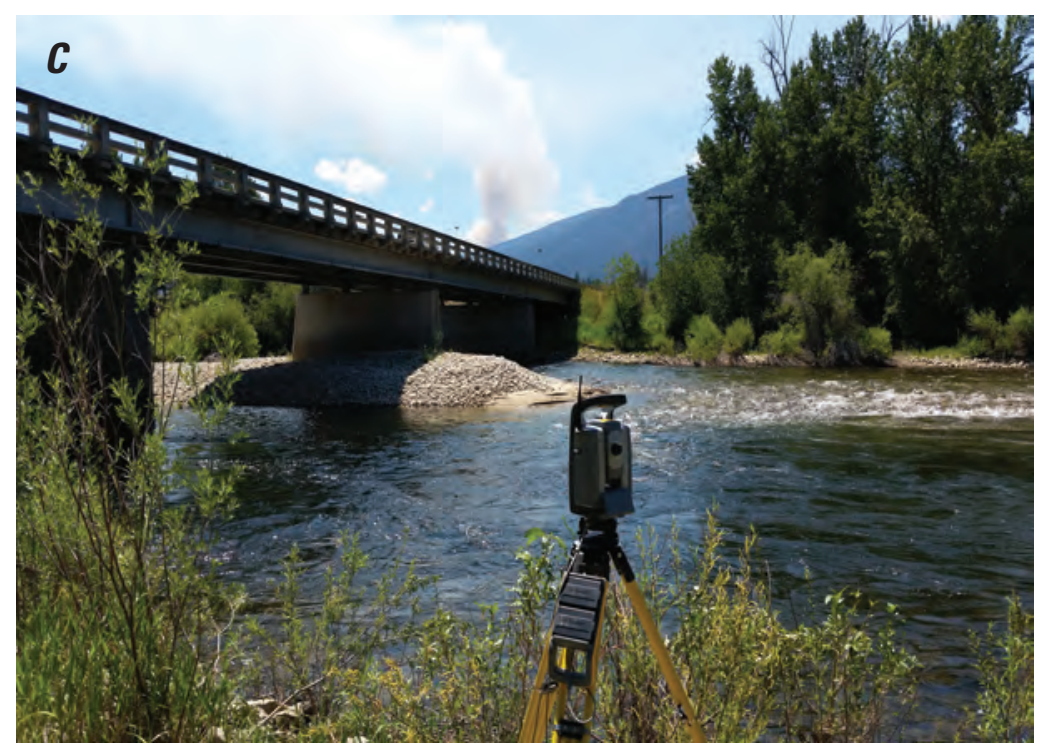


can rapidly collect data in an approximately 130-m sphere around the unit. The smaller size and rapid data-collection ability make the FARO scanner useful for surveying smaller bridge sites. Data were obtained by allowing the FARO unit to rotate 360 degrees at several (up to 12) different tripod setups throughout the surveyed reach, using reference spheres to align the scan from each setup with other scans.

The Trimble VX, a stationary three-dimensional single-laser scanner (Trimble, 2010), also was used at some Category 1 and 2 sites (005 and 006) to collect topographic data (fig. 15C). Topographic data were collected within a selected area and scanned at a target resolution of about 0.3 to $1.0 \mathrm{~m}$ along the banks, and 0.1 to $0.3 \mathrm{~m}$ along the piers.

For the tripod-mounted T-lidar systems, field procedures similar to those described in Kimbrow and Lee (2013) were followed during data collection. A surveying methodology was employed with the intent of one-sided coverage of features on the banks of the surveyed river reach.

As with the Category 1 and 2 sites, the data from the tripod T-lidar were parsed, processed, and integrated into cohesive datasets for visualization and cleanup. The ILRIS T-lidar data were parsed in the Teledyne-Optech Parser executable to process the raw data into multiple XYZ datasets with signal return intensity, one for each pivot step at a given tripod setup. The FARO T-lidar data were processed in the FARO Scene software, which allows multiple FARO scan files to be aligned using reference targets, and common topographic features between the scan files and output to multiple XYZ datasets with intensity, one for each scanner setup. Additionally, with the FARO T-lidar data, photographs taken concurrently with the lidar data can be used to apply a three-value red-green-blue (RGB) color to each point in the lidar point cloud. These colorized point clouds also were output to multiple XYZ datasets with RGB color, one for each scanner setup.

The various XYZ files for a given survey were combined into a single topographic dataset and visualized in the PolyWorks IM-Align and IM-Survey software packages. The data were aligned and georeferenced using coordinates for the various reference targets and spheres in the surveyed area. The processed and edited data collected with the ILRIS HD ER unit were output to a space-delimited XYZ dataset with intensity, one file for each survey, and are included with the metadata in data releases by Dudunake $(2017,2019)$. The processed and cleaned data collected with the FARO unit were output to two space-delimited XYZ datasets, one with intensity and the other with RGB color (one of each per survey), and are also included with the metadata in the two data releases (Dudunake, 2017, 2019). A sample of these colored T-lidar data are shown in figure 2. At sites where available $(001,003,004,007$, and 030), bathymetric data were combined with the T-lidar data obtained at each site (fig. 16).

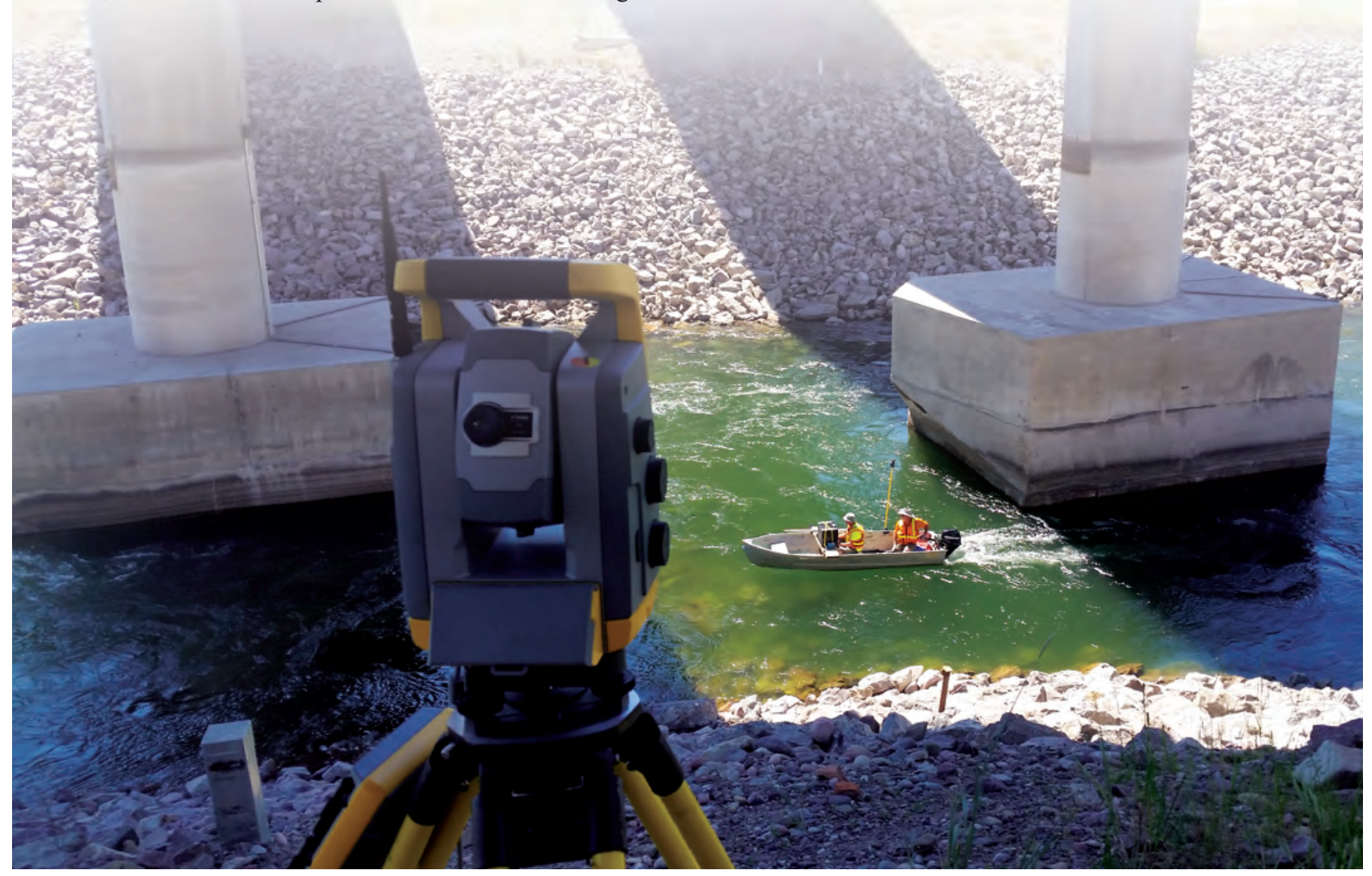

U.S. Geological Survey field crew Stephen Holnbeck and Sean Lawlor surveying bathymetry near two large piers at bridge over Blackfoot River at I-90 at Bonner, Montana (site 016). Photo by Taylor Dudunake, U.S. Geological Survey. 


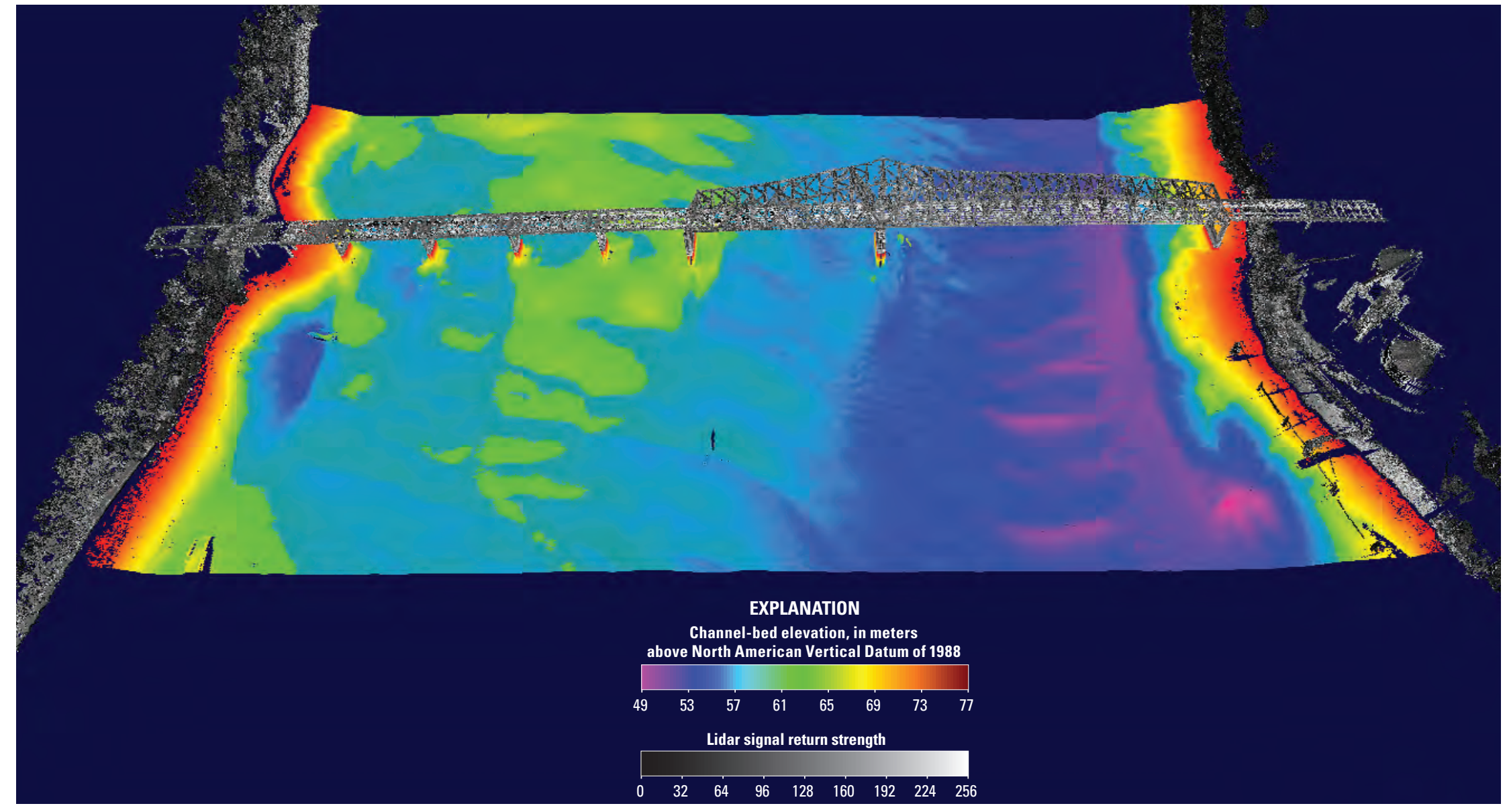

Figure 16. Oblique view (from downstream [southeast]) of the terrestrial lidar scanned data merged with channel bathymetry survey data of the bridge and river channel at site 004, Interstate 155 over the Mississippi River near Caruthersville, Missouri, from May 3, 2016 
The alignment error for each of the tripod-mounted T-lidar surveys was determined based on the difference in the relative easting, northing, and elevation values obtained for the center of the reference spheres or targets around the site, using the position of the virtual reference points at the center of each target to align the survey with real-world coordinates for those targets, determined by use of GNSS and conventional surveying methods. The alignment and georeferencing errors are documented in the various metadata files in data releases (Dudunake, 2017, 2019).

\section{Flood History at Study Sites}

In most cases, the flood history at each site was derived from streamflow records of the USGS streamgage along the same stream that the bridge spanned. In a few cases, a streamgage on another nearby stream was used to estimate the flood conditions on the river or stream passing under the study bridge because direct streamflow data were not available. At these sites, the regional flood frequency equations in StreamStats were used to determine the AEP of the estimated peak streamflows. Countermeasures were installed at the 34 selected bridges from as early as 1973 for site 004, Mississippi River at I 55 (A1700) near Caruthersville, Missouri, to as recently as 2011 for site 002, Spring Creek at US-231 near Cambellton, Florida. Flood frequency statistics were estimated using methods from published reports for each state where a study site was located.

The published USGS flood frequency methods that were used typically conform to the guidelines set forth in Bulletin 17B (Interagency Advisory Committee on Water Data, 1982). In 2018, Bulletin 17C (England and others, 2018) was released with new guidelines for determining flood-flow frequency, but since this study uses previously published statistics developed using Bulletin 17B guidelines, the new guidelines were generally not referenced in this report. Frequency analysis of annual peak streamflow at streamgages provides a means of estimating the probability of occurrence of a given streamflow. Flood frequency is commonly expressed in terms of the probability of being exceeded, or a recurrence interval (the recurrence interval is the reciprocal of the AEP). For example, a flood having an annual AEP of 0.01, which is equivalent to a 1-percent chance of being equaled or exceeded in any given year, is often referred to as a "100-year flood." The guidelines described in Bulletin 17B include methods for computing atsite statistics, use of regional regression equations to estimate statistics at ungaged locations, and methods for computing weighted statistics for locations on gaged streams. At gaged locations, or at ungaged locations within allowable limits along a gaged stream, the weighted statistics are considered the most reliable values, therefore, whenever possible, weighted flood frequency statistics were used to estimate the AEPs of the highest three floods known to have occurred since the countermeasures were installed.

\section{Peak Streamflow History Since Countermeasures Were Installed}

A summary of the maximum streamflows known to have occurred since countermeasures were installed at sites in this study are presented in table 3. Additional data are available in Dudunake and others $(2017,2019)$. The initial criteria for study site selection included peak streamflows that equaled or exceeded the 4-percent AEP since countermeasures were installed. Although only 22 of 34 sites met the 4-percent AEP requirement, all sites met the revised requirement of peak streamflows greater than or equal to the 10-percent AEP. At 13 of the 34 sites, an extreme flooding event was documented after countermeasures were installed, with peak streamflows that equaled or exceeded the 1-percent AEP (fig. 17), and a subset of those sites experienced peak streamflows with an AEP of less than 0.2 percent (greater than the 500-year recurrence interval). At 20 of 34 sites, the maximum streamflows after countermeasures were installed occurred in 2011 and ranged in exceedance probability from 20 percent to less than 0.2 percent. Some scour holes and shifting and distress to countermeasures were noted, but field inspections did not indicate any major failures of scour countermeasures. Evaluation of the conditions of the countermeasures indicated that they generally remained in place as intended during moderate flooding, and in some cases, during floods of magnitudes greater than the 1-percent AEP. Detailed analysis of the performance of scour countermeasures during flood flows was beyond the scope of this study, but the data collected were provided to the FHWA for use in evaluating the performance of scour countermeasures and to assist in evaluating scour protection guidelines. 
Table 3. Peak streamflow since scour countermeasures were installed, 1-percent annual exceedance probability, and 1-percent annual exceedance probability discharge at 34 bridge-scour countermeasure assessment sites used in this study.

[AEP, annual exceedance probability, ft³/s, cubic feet per second; FL, Florida; MO, Missouri; ID, Idaho; IL, Illinois; PA, Pennsylvania; CT, Connecticut; MT, Montana; IA, Iowa; NJ, New Jersey; --, not available; $<$, less than]

\begin{tabular}{|c|c|c|c|c|c|c|}
\hline $\begin{array}{c}\text { Site } \\
\text { identifier }\end{array}$ & Site name & $\begin{array}{c}\text { Year } \\
\text { countermeasure } \\
\text { was installed }\end{array}$ & $\begin{array}{l}\text { Peak streamflow since } \\
\text { countermeasures } \\
\text { were installed } \\
\left(\mathrm{ft}^{3} / \mathrm{s}\right)\end{array}$ & $\begin{array}{c}\text { Year of } \\
\text { peak } \\
\text { discharge }\end{array}$ & $\begin{array}{l}\text { AEP of peak } \\
\text { discharge } \\
\text { (percent) }\end{array}$ & $\begin{array}{c}\text { 1-percent } \\
\text { AEP } \\
\text { discharge } \\
\left(\mathrm{ft}^{3} / \mathrm{s}\right)\end{array}$ \\
\hline 1 & Apalachicola River at I-10 (SR 8), near Chattahoochee, FL & 2000 & 159,000 & 2005 & 10 & 248,500 \\
\hline 2 & Spring Creek at US-231, near Cambellton, FL & 2011 & 10,000 & 2013 & -- & -- \\
\hline 3 & Mississippi River at US-54, (K0932) at Louisiana, MO & 1992 & 456,000 & 2008 & $0.5-1$ & 1-- \\
\hline 4 & Mississippi River at I-155 (A1700), near Caruthersville, MO & 1973 & $2,040,000$ & 2011 & 1 & ${ }^{1--}$ \\
\hline 5 & Snake River at Ferry Butte Road (W 500 S), Bingham County, ID & 2002 & 28,700 & 2011 & 20 & 42,320 \\
\hline 6 & Snake River at Shelley West River Road (E 1250 N) near Shelley, ID & 2002 & 32,300 & 2011 & 10 & 54,320 \\
\hline 7 & Wabash River at I-64 (097-0003/0004), near Grayville, IL & 2009 & 270,000 & 2011 & 4 & 323,200 \\
\hline 8 & Thompson River at MO-6 (A0906), near Trenton, MO & 2006 & 78,200 & 2014 & 2 & 79,300 \\
\hline 9 & Fox River at US-61 (A4584), near Wayland, MO & 2009 & 26,600 & 2011 & 1 & 26,700 \\
\hline 10 & Perkiomen Creek and Mill Race at Salford Station Road (SR1024) near Perkiomenville, PA & 2012 & 26,600 & 2011 & 2 & 30,300 \\
\hline 11 & Grand River at Rte-A (P0250) near McFall, MO & 2001 & 55,000 & 2007 & 1 & 56,500 \\
\hline 12 & West Branch Brandywine Creek at Strasburg Road (SR 3062) near Coatesville, PA & 2008 & 7,000 & 2014 & 10 & 14,200 \\
\hline 13 & Byram River at Sherwood Ave (05018) at Greenwich, CT & 2010 & 1,700 & 2011 & 10 & 3,560 \\
\hline 14 & Bitterroot River at US-93 near Hamilton, MT & 2004 & 12,000 & 2009 & 10 & 17,700 \\
\hline 15 & Bitterroot River at Bell Crossing near Victor, MT & 2004 & 13,700 & 2011 & 20 & 22,600 \\
\hline 16 & Blackfoot River at I-90 at Bonner, MT & 2004 & 17,200 & 2011 & 4 & 21,300 \\
\hline 17 & Clark Fork River at Turah Road, near Bonner, MT & 2006 & 13,400 & 2011 & 10 & 20,200 \\
\hline 18 & Beaverhead River at MT-41 at Twin Bridges, MT & 2009 & 3,100 & 2011 & 210 & 3,571 \\
\hline 19 & Gallatin River at I-90, near Manhattan, MT & 2006 & 9,360 & 2011 & 4 & 11,200 \\
\hline 20 & Jefferson River at MT-2 near Three Forks, MT & 2008 & 17,700 & 2011 & 4 & 20,200 \\
\hline 21 & Madison River at I-90 near Three Forks, MT & 2004 & 8,050 & 2011 & 10 & 10,700 \\
\hline 22 & Gallatin River at S-205, near Manhattan, MT & 2006 & 9,360 & 2011 & 4 & 11,200 \\
\hline 23 & Judith River at MT-81, near Lewistown, MT & 2006 & 11,690 & 2011 & 0.5 & 8,350 \\
\hline 24 & Musselshell River at S-300, at Ryegate, MT & 2006 & 9,190 & 2011 & 1 & 9,530 \\
\hline 25 & Tongue River at I-94, at Miles City, MT & 2001 & 15,300 & 2011 & 2 & 17,700 \\
\hline 26 & Two Medicine River at US-89, near Browning, MT & 2008 & 7,940 & 2011 & 20 & 38,400 \\
\hline 27 & Yellowstone River at Hwy 312 at Huntley, MT & 2008 & 73,700 & 2011 & 4 & 81,800 \\
\hline 28 & Smith Branch at S-126 (Clement Rd) at Columbia, SC & 1998 & 5,030 & 2015 & $<0.2$ & 3,130 \\
\hline 29 & Black River at US-52 at Kingstree, SC & 1998 & 83,700 & 2015 & $<0.2$ & 33,800 \\
\hline 30 & Upper Iowa River at IA-76 near Dorchester, IA & 2001 & 38,000 & 2016 & 0.2 & 28,800 \\
\hline 31 & Wapsipinicon River at US-30 near Wheatland, IA & 2000 & 37,200 & 2014 & 1 & 33,600 \\
\hline 32 & Old Man's Creek at IA-1 near Iowa City, IA & 2007 & 13,900 & 2013 & 2 & 16,900 \\
\hline 33 & Yellow Brook at NJ-34 at Colts Neck Township, NJ & 2008 & 2,030 & 2011 & $0.2-1$ & ${ }^{2} 1,670$ \\
\hline 34 & Saddle River at NJ-17 at Ridgewood, NJ & 2009 & 6,770 & 2011 & $0.2-1$ & 6,320 \\
\hline
\end{tabular}

21-percent annual exceedance probability (AEP) discharge determined from regional flood frequency equations (U.S. Geological Survey, 2016b) 


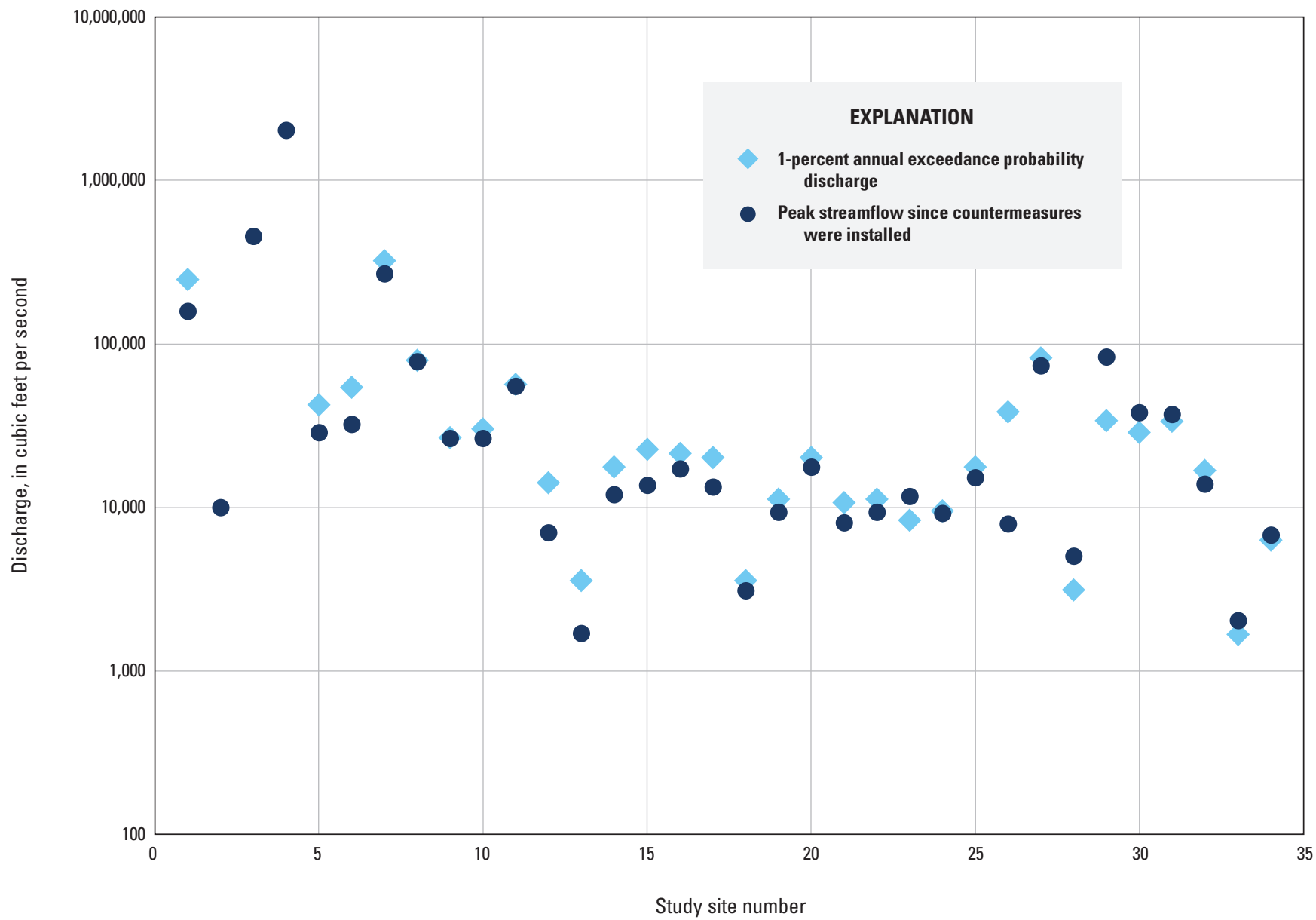

Figure 17. Plot of 1-percent annual exceedance probability discharge and maximum recorded discharge since countermeasures were installed at 34 study sites.

\section{Summary}

The catastrophic bridge failure of the New York State Thruway bridge over Schoharie Creek in 1987 transformed the science and engineering communities' understanding of risk associated with scour around bridges. The Federal Highway Administration (FHWA) Hydrologic Engineering Circulars (HECs) 18, 20, and 23 provided guidance on bridge scour, stream instability, and the selection and design of scour countermeasures, however, even after years of implementation, a broad evaluation of installed countermeasures at bridge sites had not been conducted. In 2013, the U.S. Geological Survey (USGS), in cooperation with the FHWA, began a study to assess the condition of bridge scour countermeasures at selected sites across the United States.

This study collected data at 34 bridge sites with scour countermeasures installed following guidelines presented in FHWA HEC 18 and HEC 23. In addition to following FHWA guidelines for the design and installation of countermeasures, study site selection criteria included a requirement for annual peak streamflow data and at least one documented streamflow that equaled or exceeded the 4-percent annual exceedance probability (AEP) after installation of the countermeasures. This criterion could not be met at some sites, so some exceptions were made to accept sites with streamflows that equaled or exceeded the 10-percent AEP. The USGS used traditional survey methods, global navigation satellite systems, terrestrial light detection and ranging technology scanning, underwater cameras, and single- and multibeam sonar technology to collect data that describe the stream channel conditions, bridges, and countermeasures. Furthermore, adjustments were made to procedures and setup parameters of the multibeam sonar systems to facilitate the collection of riprap stone sizes at sites with submerged countermeasures. Using these methods, installed countermeasures were inspected to determine existing placement, general quantity, and visible condition relative to installation plans. The presence of any notable scour holes around the bridge abutments, piers, and countermeasures, washouts, slumping, or movement were documented. The countermeasures that were evaluated can be combined into 
five general categories: riprap, A-Jacks, cabled-concrete mattresses, articulated concrete block matting, and Gabion baskets. Data for the 34 study sites were published in two USGS Open-File Reports and associated data releases. Site evaluation reports documented that most of the countermeasures evaluated seemed to generally remain in place, but some scour holes, movement, and slumping were found. Streamflow data were used to determine conditions at countermeasure sites since they were installed to estimate potential scour conditions from flood flows. It was estimated that at least 13 of the 34 bridge study sites experienced peak streamflows that were less than the 1-percent AEP (greater than a 100-year recurrence interval), and 22 of the 34 study sites experienced peak streamflows that met or exceeded the 4-percent AEP (greater than a 25 -year recurrence interval).

All of the data collected during this study were provided to the FHWA to aid in assessing the performance of the scour countermeasures. Continued inspection and evaluation of scour countermeasures will provide valuable information to assist the FHWA with improving existing guidelines.

\section{References Cited}

Applanix Corporation, 2006, POS-MV V4 user guide, rev. 0: Richmond Hill, Ontario, Canada, PUBS-MAN-000513, 369 p.

Applanix Corporation, 2009, POS-Pac MMS GNSS-inertial tools user guide, rev. 4: Richmond Hill, Ontario, Canada, PUBS-MAN-001768, 523 p.

Bryan, B.A., 1989, Channel evolution of the Hatchie River near the U.S. Highway 51 Crossing in Lauderdale and Tipton Counties, West Tennessee: U.S. Geological Survey Open-File Report 89-598, 59 p. [Also available at https:// pubs.usgs.gov/of/1989/ofr_89-598/pdf/ofr_89-598_a.pdf.]

Byrnes, M.R., Baker, J.L., and Li, Feng, 2002, Quantifying potential measurement errors and uncertainties associated with bathymetric change analysis: Vicksburg, Mississippi, U.S. Army Corps of Engineers, ERDC/CHL CHETN-IV-50, 17 p., accessed September 26, 2018, at http://apps.dtic.mil/ dtic/tr/fulltext/u2/a588888.pdf.

Calder, B.R., and Mayer, L.A., 2003, Automatic processing of high-rate, high-density multibeam echosounder data: Geochemistry, Geophysics, Geosystems, v. 4, no. 6, 22 p., accessed May 20, 2019, at https://doi. org/10.1029/2002GC000486.

Densmore, B.K., Strauch, K.R., and Dietsch, B.J., 2013, Hydrographic surveys of the Missouri and Yellowstone Rivers at selected bridges and through Bismarck, North Dakota, during the 2011 flood: U.S. Geological Survey Scientific Investigations Report 2013-5087, 59 p. [Also available at https://pubs.usgs.gov/sir/2013/5087/.]
Dudunake, T.J., 2017, Geospatial data for bridge scour countermeasure assessments at select bridges in the United States, 2014 to 2016: U.S. Geological Survey data release, https://doi.org/10.5066/F71R6NQ2.

Dudunake, T.J., 2019, Geospatial data for bridge scour countermeasure assessments at select bridges in the United States, 2016-18: U.S. Geological Survey data release, https://doi.org/10.5066/F7WW7G4W.

Dudunake, T.J., Huizinga, R.J., and Fosness, R.L., 2017, Bridge scour countermeasure assessments at select bridges in the United States, 2014-16 (ver. 1.1, October 2017): U.S. Geological Survey Open-File Report 2017-1048, 10 p., accessed May 20, 2019, at https://doi.org/10.3133/ ofr20171048.

Dudunake, T.J., Huizinga, R.J., and Fosness, R.L., 2019, Bridge scour countermeasure assessments at select bridges in the United States, 2016-18: U.S. Geological Survey Open-File Report 2019-1008, 12 p., accessed May 12, 2019, at https://doi.org/10.3133/ofr20191008.

England, J.F., Jr., Cohn, T.A., Faber, B.A., Stedinger, J.R., Thomas, W.O., Jr., Veilleux, A.G., Kiang, J.E., and Mason, R.R., Jr., 2018, Guidelines for determining flood flow frequency-Bulletin 17C: U.S. Geological Survey Techniques and Methods, book 4, chap. B5, 148 p., accessed May 20, 2019, at https://doi.org/10.3133/tm4B5.

Federal Highway Administration, 2009, Bridge scour and stream instability countermeasures: Experience, selection and design guidance (3d ed., v. 1): Hydraulic Engineering Circular, No. 23, Publication No. FHWA-NHI-09-111, 256 p. [Also available at https://www.fhwa.dot.gov/engineering/ hydraulics/pubs/09111/09111.pdf.]

Federal Highway Administration, 2012a, Evaluating scour at bridges (5th ed.): Hydraulic Engineering Circular, No. 18, Publication No. FHWA-HIF-12-003, 340 p. [Also available at https://www.fhwa.dot.gov/engineering/hydraulics/pubs/ hif12003.pdf.]

Federal Highway Administration, 2012b, Stream stability at highway structures (4th ed.): Hydraulic Engineering Circular, No. 20, Publication No. FHWA-HIF-12-004, 328 p. [Also available at https://www.fhwa.dot.gov/engineering/ hydraulics/pubs/hif12004.pdf.]

Federal Highway Administration, 2016, Standard Method of Test for Determining Riprap Gradation by Wolman Count: U.S. Department of Transportation Office of Federal Lands Highway, accessed January 23, 2017, at https://flh.fhwa.dot. gov/resources/materials/fmm/documents/FLH-T-521.pdf.

FARO Technologies, 2014, FARO Laser Scanner Focus3D X130 Operation Manual: Lake Mary, Florida, 118 p. 
Holnbeck, S.R., and McCarthy, P.M., 2009, Monitoring hydraulic conditions and scour at I-90 Bridges on Blackfoot River following removal of Milltown Dam near Bonner, Montana, in Burns, S.E., Bhatia, S.K., Avila, C.M.C., and Hunt, B.E., eds., Proceedings of 5th International Conference on Scour and Erosion: San Francisco, California, American Society of Civil Engineers, 11 p.

Huizinga, R.J., 2010, Bathymetric surveys at highway bridges crossing the Missouri River in Kansas City, Missouri, using a multibeam echo sounder, 2010: U.S. Geological Survey Scientific Investigations Report 2010-5207, 61 p. [Also available at https://pubs.usgs.gov/sir/2010/5207/.]

Huizinga, R.J., Elliott, C.M., and Jacobson, R.B., 2010, Bathymetric and velocimetric survey and assessment of habitat for pallid sturgeon on the Mississippi River in the vicinity of the proposed Interstate 70 Bridge at St. Louis, Missouri: U.S. Geological Survey Scientific Investigations Report 2010-5017, 28 p. [Also available at https://pubs.usgs.gov/ $\operatorname{sir} / 2010 / 5017 /$.

Huizinga, R.J., and Wagner, D.M., 2019, Erosion monitoring along selected bank locations of the Coosa River in Alabama using terrestrial light detection and ranging (T-Lidar) technology, 2014-17: U.S. Geological Survey Scientific Investigations Report 2019-5023, 28 p., accessed May 20, 2019, at https://doi.org/10.3133/sir20195023.

HYPACK, Inc., 2015, HYPACK hydrographic survey software user manual: Middletown, Connecticut, HYPACK, Inc., 2,041 p.

Interagency Advisory Committee on Water Data, 1982, Guidelines for determining flood flow frequency: Hydrology Subcommittee Bulletin 17B (Distributed by U.S. Geological Survey, Office of Water Data Coordination, Reston, Virginia), 183 p., accessed May 20, 2019, at https://water.usgs. gov/osw/bulletin17b/dl_flow.pdf.

Kimbrow, D.R., and Lee, K.G., 2013, Erosion monitoring along the Coosa River below Logan Martin Dam near Vincent, Alabama, using terrestrial light detection and ranging (T-LiDAR) technology: U.S. Geological Survey Scientific Investigations Report 2013-5128, 7 p. [Also available at http://pubs.usgs.gov/sir/2013/5128/.]

Lee, K.G., 2013, Estimation of reservoir storage capacity using multibeam sonar and terrestrial lidar, Randy Poynter Lake, Rockdale County, Georgia, 2012: U.S. Geological Survey Scientific Investigations Map 3265, 1 sheet. [Also available at https://pubs.usgs.gov/sim/3265/.]

Rydlund, P.H., Jr., and Densmore, B.K., 2012, Methods of practice and guidelines for using survey-grade global navigation satellite systems (GNSS) to establish vertical datum in the United States Geological Survey: U.S. Geological Survey Techniques and Methods, book 11, chap. D1, 102 p., with appendixes.
Teledyne-Optech, 2012, ILRIS Laser Scanner Operation Manual: Vaughan, Ontario, Canada, Teledyne-Optech, Inc., Issue 0040170/Rev G., 288 p.

Trimble, 2010, Trimble VX Spatial Station User Guide: Dayton, Ohio, Trimble Navigation Limited, Engineering and Construction Division, Version 6.0, Part Number 573460002, January 2010.

U.S. Army Corps of Engineers, 2004, Upper Mississippi River System Flow Frequency Study: U.S. Army Corps of Engineers, Rock Island District, accessed April 18, 2019, at http://www.mvr.usace.army.mil/Missions/Flood-Risk-Management/Upper-Mississippi-Flow-Frequency-Study/.

U.S. Army Corps of Engineers, 2014, RiverGages.com, Water levels of rivers and lakes: U.S. Army Corps of Engineers, accessed August 1, 2014, at http://rivergages.mvr.usace.army.mil/WaterControl/stationinfo2. cfm? $\mathrm{sid}=\mathrm{MS} 117 \&$ fid $=\mathrm{CRTM} 7 \& \mathrm{dt}=\mathrm{S}$.

U.S. Geological Survey, 2016a, USGS water data for the Nation: U.S. Geological Survey National Water Information System database, accessed December 6, 2016, at https://doi. org/10.5066/F7P55KJN.

U.S. Geological Survey, 2016b, Streamflow Statistics and Spatial Analysis Tools for Water-Resources Applications (StreamStats): U.S. Geological Survey website, accessed November 18, 2016, at https://water.usgs.gov/osw/streamstats/.

Zembrzuski, T.J., Jr., and Evans, M.L., 1989, Flood of April 4-5, 1987, in Southeastern New York State, with flood profiles of Schoharie Creek: U.S. Geological Survey WaterResources Investigations Report 89-4084, 41 p. [Also available at https://pubs.usgs.gov/wri/1989/4084/report.pdf.] 

For additional information, contact:

Director, New Jersey Water Science Center U.S. Geological Survey

3450 Princeton Pike, Suite 110

Lawrenceville NJ 08648

Or visit our website at: https://www.usgs.gov/centers/nj-water

Publishing support provided by the West Trenton Publishing Service Center 
